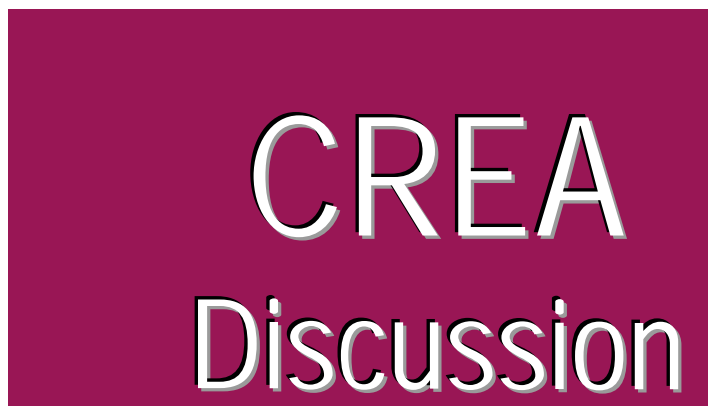
Paper

\title{
2014-25
}

Center for Research in Economics and Management University of Luxembourg

\section{Emergence of Sovereign Wealth Funds}

available online : http://wwwfr.uni.lu/recherche/fdef/crea/publications2/discussion_papers

Jean-François Carpantier, CREA, Université de Luxembourg

Wessel N. Vermeulen, OxCarre, University of Oxford

November, 2014

For editorial correspondence, please contact: crea@uni.lu

University of Luxembourg

Faculty of Law, Economics and Finance

162A, avenue de la Faïencerie

L-1511 Luxembourg 


\title{
Emergence of Sovereign Wealth Funds
}

\section{0th November 2014}

\author{
J.-F. Carpantier ${ }^{\mathrm{a}}$, W. N. Vermeulen ${ }^{\mathrm{b}}$ \\ ${ }^{a}$ University of Luxembourg, CREA \\ ${ }^{b}$ University of Oxford, OxCarre
}

\begin{abstract}
This paper tests the theoretically founded hypothesis that the surge of SWF establishments is determined by three main factors: 1) the existence of natural resources profits, 2 ) the government structure and 3) the ability to invest usefully in the domestic economy. We test this hypothesis on a sample of 20 countries that established an SWF in the period 1998-2008 by comparing them to the roughly 100 countries that did not set up a fund in the same period. We find evidence for all three factors. The results suggest that SWFs tend to be established in countries that run an autocratic regime and have difficulties finding suitable opportunities for domestic investments. We do not find the net foreign asset position of a country to be similarly related to the explanatory variables, indicating that the establishment of an SWF is distinct from a national accounting result. We argue that our results indicate that it is relevant to study how an SWF interacts with the domestic economy and government policy.
\end{abstract}

Keywords: Sovereign Wealth Fund, Institutions, natural resources

JEL classification: E21, E62, F39, G23, H52

Email addresses: jean-francois.carpantier@uni.lu (J.-F. Carpantier), wessel.vermeulen@economics.ox.ac.uk (W. N. Vermeulen)

We like to thank Michel Beine, Quentin David, Anastasia Litina, Paul Beaudry, Tony Venables Rick van der Ploeg and seminar participants at ESOP, Oslo, CREA, Luxembourg, OxCARRE, Oxford and the Conference on Econometric Methods for Banking and Finance, Lisboa, for helpful comments. 


\section{Introduction}

Of the 37 countries with at least one Sovereign Wealth Fund (SWF) today, whose combined (estimated) assets under management amount to US\$6 trillion (US\$3.5 trillion for non-pension funds), 22 countries have established such a fund since 1998, representing $35 \%$ of the total assets. Of these 22 countries, 11 are governed by autocratic or less democratic governments, while such countries represent less than a third of the total number of countries in the world. ${ }^{2}$ This surge in government controlled funds can partly be explained by the rise in commodity prices since the late 1990, which suddenly made many of the lower income countries' governments awash with hard currency. These funds typically hold low risk assets in foreign, often high-income, countries. Standard theory would advise that one should save temporary income to finance long-term consumption. However, when a country is characterised by capital scarcity the optimal policy may be to invest in the domestic economy to trigger long-term economic growth. Therefore the choice of setting up a fund is determined by economic circumstances of the country, but also, as the distribution of funds around the world shows, by the political structure in which this decision takes place.

This paper tests the theoretically founded hypothesis that the surge of SWF establishments is in equal parts determined by the existence of natural resources profits, the government structure and the ability to invest profitably in the domestic economy. Natural resources are a precondition for many SWFs as their exploitation offers substantial and multi-year funding. Based on this, one would expect to observe many countries with an SWFs in the world. However, many 'western' countries, who had and still have oil revenues, have not chosen the structure of an SWF to save this income. ${ }^{3}$ Non-democratic countries have been more eager to set up such funds. Natural resources exploitation has often been related to corruption. An SWF may be both an improvement of the past towards the managements of the resource windfalls as well as a fig leaf.

We compare the existence of an SWF with the possibility to invest at home in (public) capital. An SWF focused on foreign investments cannot achieve a higher return than the average world interest rate. In contrast, a long-term horizon in a capital scarce country would favour investments in human and physical capital at home that would benefit sustainable economic growth for the long-term future. However, such a long-term horizon may not exist for autocratic regimes more concerned with their immediate survival in a country with rivals for leadership. In democratic countries the short term view rooted

\footnotetext{
${ }^{2}$ Calculations based on data of the SWF Institute and other sources. 'Non-democratic' defined as a value of 0 or lower at the polity2 scale. See further Section 4

${ }^{3}$ Of European countries, US, Canada, Australia and New Zealand, only Norway has famously a sizeable Sovereign Wealth Fund, whereas in the US and Canada relatively small local funds exist. The Netherlands and the UK never set up a similar structure to deal with their North Sea oil revenue. See further the discussion in section 4
} 
in election cycles is arguably mitigated by voters' concern for the generations that follow them.

We use the sudden emergence of new SWFs to test for the role of economic and political factors in their establishments using logistic regressions. We argue that the sudden emergence of SWFs in recent times was triggered by a commodities price boom that was outside of the control of individual countries. As control group, we use all countries that have not set up an SWF. Identification relies on strict time separability where past determinants relate to future establishments. We find that resource rents are a strong predictor for the establishment of an SWF. However, given our sample, these rents become less important once we control for a government's scale of autocracy. Past expenditures on public goods such on education predict a lower probability of establishing an SWF in the future indicating that some countries have made a trade-off between domestic and foreign investments. We find that natural resources are a special case as the more general current account does not give the same results. Similarly, the variables that are robustly related to the probability of establishing an SWF are not similarly related to the countries foreign asset position. The decision of establishing an SWF can therefore be interpreted as a policy instrument that is used by certain states, but is not necessarily in direct correspondence to macro-financial circumstances.

There exists a variety in the qualitative characteristics of SWFs. Some are better managed and more transparent in their investments and obligations to the government than others. Many of the recent SWFs have a particularly small asset base relative to the potential windfall that it could manage, indicating that the fund may be set up primarily for political reasons rather than for genuine implementation of an optimal saving policy for future generations. In fact the surge of SWFs establishments in autocratic countries with little experience of market-based investments gave rise to a lively discussion (especially in the US) on the potentially international political reasons behind these investments. This in turn motivated some stakeholders to call for a regime of 'best practices' that could ensure that government-controlled funds invest for economic and financial reasons reasons in transparent ways.

Therefore, this article contributes to two different strands in the literature of resource management and international finance. On the one hand, our results suggest that SWFs from non-democratic regimes are probably not established to take over the free world. Instead, their emergence points to defects at origin: the inability, or unwillingness, to direct the funds towards improving the domestic economy. Discussions should therefore continue to include why SWFs hold most of their funds in foreign investments, while improving the domestic investment climate may reap much higher benefits.

On the other hand, the literature that debates the different strategies of harnessing resource windfalls may be comforted by the fact that current SWFs appear to take domestic investment opportunities already into account. Domestic characteristics are a 
strong determinant of SWFs establishments, which are therefore not the result of an abstract and stylised savings decision. Theoretical predictions on the barriers to investment and rivalrous rent-seeking are also confirmed. This suggests again that the resource rents are currently not always used for the benefit of the development of the country.

To our knowledge, no paper on SWFs specifically addresses the question of the emergence of the SWFs and of the determinants leading countries to decide to set-up such funds. The only notable exception is the paper of Aizenman and Glick (2009) which studies the determinants of the existence (but not the emergence) in 2007 or 2008 of Sovereign Wealth Funds. They find that current account surpluses, fuel exports and foreign exchange reserves are significant in explaining the existence of an SWF. They also explore the role of government indicators (proxied by the Worldwide Governance Indicators of Kaufmann et al., 2009). We improve on their paper with a more carefully econometric set-up, using a dataset with which we are able to draw stronger causal relationships between economic-political country characteristics and the establishments of SWFs. We also relate directly to theoretical literature on resource wealth management, and test various predictions derived from this literature.

\section{Literature Review}

Our study on the emergence of Sovereign Wealth Funds is at the crossroad of different research fields: one devoted to the SWF phenomenon in general, one devoted to the management of large current account surpluses (including resource revenues) and one on optimal foreign exchange reserves.

It is firstly, related to the literature on Sovereign Wealth Funds in general. Two core sub-fields have emerged over last decade, a finance one and a political one. On the finance side, one question is whether such massive funds could have an impact on the financial markets, and whether this effect is good (enhanced liquidity, long-run investment horizons) or bad (systemic risks, volatility). On the one hand, Beck and Fidora (2008) and Sun and Hesse (2009) evaluate the short-term financial impact of SWFs on selected public equity markets in which they invest and found no significant destabilizing effect. On the contrary, Kotter and Lel (2008) find a significant, and positive, return announcement effect. In et al. (2013) and Gomes (2008) on the other hand explore their long-run stabilising role. The question of their performance given their specific governance (political influences, long-term investment horizon, opacity) has also been explored (Bernstein et al., 2013; Ang, 2012). On the political side, some specific investments gave rise to hot political debate on whether such politically-flavoured investors could be a threat to national security (Kirshner, 2009) and could indirectly encourage capital account protectionism (Johnson, 2007). The scope of this branch of papers relates to business practices such as corporate governance and ethics. Monk (2009) argues that it is rather perceptions that recipient countries may have of the SWFs, rather than actual past (mis-)behaviour that 
drives the general negative attitude against them. The SWFs are not helping by being generally opaque on their governance structure, investment objectives and strategy.

Remarkably, these studies often discard the domestic factor (from the perspective of the SWFs), and do not question why a government establishes an SWF and uses it to invest abroad rather than using the revenues to invest in its own economy. Nevertheless, the background and establishments of funds is analysed for instance by Yi-Chong and Bahgat (2010) as well as by NGO's/Academic research institutes. ${ }^{4}$ From such sources it is already evident that political mechanisms, especially within countries, is a major driver for the decision to establish an SWF. We take a more macro-approach in our research by not only looking at countries that have established an SWF but by comparing these countries with those that have not.

The second research field, on the best management of large current account surpluses (including resource revenues), has two schools. On the one hand a classical school which advises saving as much as possible in order to reap long term, but incremental, benefits (Hartwick, 1977), and on the other hand those that argue for additional consumption and domestic investments in order to reach a higher growth path (Collier et al., 2009; Venables, 2010; van der Ploeg and Venables, 2011). This last school sees the emergence of an SWF as a final option after domestic opportunities have run out. Additionally, the efficiency of saving a windfall may be related to the domestic government structure. Van der Ploeg (2010b) argues theoretically that in more fractionalized societies, competition for rents makes a fund more likely. Indeed, looking at any list of SWFs, it is apparent that authoritatively-run governments dominate. The existence of investment funds run by non-democratic governments in turn ignited a debate on their policy of foreign investments. We return to these studies in more detail below to formulate some hypotheses.

Thirdly, the literature on optimal management of foreign exchange reserves offers a very relevant perspective on the emergence of SWFs. Rodrik (2006) shows that the excessive accumulation of foreign exchange reserves by many developing countries has a cost in terms of yields, that could amount to close to $1 \%$ of (their respective) GDP. This brought some central banks with large reserves to consider alternative more risky investments in equity, private equity markets and to progressively evolve into de facto SWFs. This is the case of the Saudi Arabian central bank (Saudi Arabian Monetary Agency or SAMA) which was estimated to have $15 \%$ of its holdings in equity in 2007 (Diwan, 2009). As second example, the Chinese State Administration of Foreign Exchanges (SAFE) established a subsidiary in Hong-Kong in 1997 to make purchases in foreign equity investment. As third example, the Swiss Central Bank announced in 2010 to have more than $10 \%$ of

\footnotetext{
${ }^{4}$ See for instance the fund profiles given by http://ccsi.columbia.edu/work/projects/ natural-resource-funds/, created in cooperation with the National Resource Governance Institute.
} 
its foreign holdings in equity (Jordan, 2012). Aizenman and Glick (2010) provide a framework to assess the optimal strategy for asset class diversification by central banks and SWFs and, given their respective objectives, to illustrate how their respective strategies are affected by various parameters such as the volatility of equity returns or the total amount of foreign assets available for management. Our perspective differs as we take the position of a government rather than of a (independent) central bank. For the latter the objective function is expressed in terms of monetary or exchange rate stability, whereas we focus on what would benefit the ruler of the country.

Our study borrows from these three fields, bringing a new contribution to the SWF literature, by looking how the resource revenue management and the foreign exchange reserve management can help to understand the emergence of SWFs. ${ }^{5}$

\section{Testable implications of theory}

There is an extensive recent literature that investigates different factors that may influence an optimal consumption, savings and investment policy for countries that face a resource exploitation windfall or may expect to do so in the future. Some of these factors are purely economic, in the sense that they relate to the structure of an economy, including the intertemporal preferences of the decision maker, and its relations with the rest of the world. Other studies relate policy decision to domestic politics and the objectives of selfinterested rulers (see Collier et al., 2009; Collier, 2010, for reviews). We expect that both types of factors will interact with the establishment of SWFs. We therefore require a careful consideration of the relevant factors and their predictions.

Before discussing these factors in detail, we need to note that the data allow us only an imperfect view of decisions. We observe the establishment of an SWF, but generally, the characteristics of those SWF, notably its size, are notoriously unreliable for the most interesting cases. In order to have the widest scope of data, we observe the most rudimentary aspect, the establishment and existence of a fund. Although we may interpret such establishment as, at least the intention of, increased savings, the recently established SWFs vary enormously in size irrespective of what could be expected from the size of resource rents available. We discuss this further in Section 6. We need to take account of these limitations of the data in formulating testable hypothesis. ${ }^{6}$

\section{H1: Resource rents increase the probability of observing an SWF.}

This hypothesis is the most obvious one. Having the means functions as a precondition to the ability to save. The reason that resource rents may in particular endure government

\footnotetext{
${ }^{5}$ Related but approaching the question on rents and savings from a different angle is the study of Andersen et al. (2013), which looks at financial flows to tax havens and relate this to variation in rents as well as governance variables.

${ }^{6}$ As usual, the test performed on the data are inverted in the sense that we test that a certain factor plays no role.
} 
saving, compared to, say, manufacturing exports surpluses is largely due to ownership. In the majority of countries the (national or regional) government maintains an important stake in the production, including through partial ownership, even when private and/or foreign firms are partners in the exploitation process. Empirically, this hypothesis also helps to identify in the estimation which among all countries in the world could potentially set up a fund.

\section{H2: Barriers to domestic investment will lead to higher foreign savings.}

Capital scarce countries may have a lot of potential in development, but certain barriers in the state of the economy prohibit their immediate exploitation. It may be argued that a country starting from a low base may not have the capacity to absorb any size of domestic investment instantaneously. Capacity for such absorption (e.g. a gradual increase in a transport network, educating teachers to scale up general education) takes time and a too large increase of investment will reduce the marginal return of these (van der Ploeg and Venables, 2013; van der Ploeg, 2012). It is not obvious to measure something like 'capacity to absorb investments'. We will primarily capture this by past education expenditures. We intend to capture with this variable the ability to absorb additional investments in public capital in general and education in particular. Past expenditures then measure the fact that there is already some infrastructure present in the country and consequently does not need to start from scratch. Therefore, past education expenditures are expected to be negatively associated with the establishment of a Sovereign Wealth Fund. Other variables may be able to capture the same mechanism. For instance, past spending on infrastructure might be such a variable. Unfortunately, not much comparable data for such specific 'beneficial' public capital are available, outside of education.

H3: Autocratic regimes are more likely to establish an SWF relative to democratic ones.

The third major determinant we like to test relates to the political determinants of savings decisions in resource rich countries. As observed above, many of the SWFs appear to be established in countries that have less than full democratic systems. And although this makes for an easy test to implement in a regression, the underlying mechanism is less clear. Several authors have looked at the dynamics of decision making in government regimes that are subject to patronage and between group rivalry. Robinson et al. (2006; 2014) introduce a model where a ruler can use government employment to support his power-base and improve the chances to stay in power. When his future value of staying in power is large enough, for instance through the expectation of future resource price rises, he will aim to stay in power through patronage and will not aim to raid all resources immediately. Although their model does not allow for the option of a government savings fund, we may postulate that as long as SWFs is not fully independently managed from the government, it can serve as ruler personal savings account. Therefore, a ruler that expects 
to stay in power for a while, may very well set up an SWF in anticipation of being able to use at least some of the proceeds for private use in the future (or for his hereditaries). When the choice is between a national savings fund and domestic investments a ruler may prefer a fund that he controls over investments in irretrievable public capital, which in the best case may only increase tax returns over the very long run. This is a similar mechanism since the discount rate applied to the future determines the choice of investments.

Van der Ploeg (2010a) models a fractionalised society where various groups exploit partially common resources that have ill-defined property rights. Since the resources are partially shared, such a society will over-extract and save too little. Although many autocratically ruled countries appear to have a diverse underlying society consisting of rival groups, we do not observe that such groups actually have the ability to extract resources for themselves. ${ }^{7}$ Hence, when the autocrat enjoys a monopoly on resource extraction he will chose for a more sustainable pattern of consumption which is accompanied by higher savings (van der Ploeg, 2010a, p. 40).

Both studies suggest that greater 'accountability' as well as well-defined property rights are instrumental for optimal behaviour of consumption, savings and investment in terms of national welfare, i.e. an SWF. The interesting counter example is here that many democratic countries, both in our sample and in the past, have not set up an SWF, or if they did, a remarkably small one. ${ }^{8}$ We will explore the political channels through the different components of regime and government characteristics included in the PolityIV dataset (Marshall et al., 2006).

This hypothesis is also the most closely related to what is known as the natural resource curse hypothesis, which relates institutions to the management and use of natural resource revenues and ultimately economic growth and development (see for instance Sachs and Warner, 2001; Mehlum et al., 2006; van der Ploeg, 2011). Note however, that we do not provide a specific test regarding this hypothesis since both economic and institution variables will be used as explanatory variables for the establishment of an SWF. Nevertheless, our results can potentially be used in future research to identify one aspect of natural resource management through a fund and how this relates to institutions and economics.

\section{H4: Debt reduction serves as an alternative to establishing an SWF.}

Apart from investing in public capital, a government that has a substantial foreign debt may choose to pay this off first before setting up an SWF. In this way, paying off debt is similarly an investment in the public good of a sound national account. Rather

\footnotetext{
${ }^{7}$ Although the case of Iraq, with the autonomous production of the Kurds, as well as the case of shared pools between Sudan and South Sudan, come to mind. In many other societies the ruling autocrat will aim to monopolise the resource exploitation

${ }^{8}$ The notable exception being Norway. The UK did not set up such a fund for its own North sea oil, while it set up the very first of such a fund for Kuwait before its independence.
} 
than the debt position it may be the borrowing costs that matter for the choice of paying down the debt (van der Ploeg and Venables, 2011). However, to our knowledge there is no comprehensive dataset available that collects government borrowing costs for the entire world. ${ }^{9}$ We will test this hypothesis instead with measures of the debt stock, and indirectly with the measures on the net financial asset position of the country.

H5: When resource windfalls are subject to future demand and price uncertainty more should be saved.

Van der Ploeg (2010a) analyses different sources of uncertainty on the national saving decision. In particular, given a government objective of minimising swings in income and spending, uncertainty originating from future resource price movements (assumed to be determined outside the power of the resource exporting country) and demand, ought to lead to additional savings. The resources should also be extracted more quickly, but the objective is to transform the wealth under ground in financial wealth with a more predictable future income flow. Sometimes such additional savings relating to mitigating resource rents volatility are known as a volatility fund since they target that aspect of the income specifically, rather than dealing with the intergenerational distribution problem (van den Bremer and van der Ploeg, 2013). Other sources of uncertainty, in particular with respect to the exact value of the resources still under the ground would induce a slower exploitation, but not a particular effect on the savings decision.

There are additional economic factors that can be captured in the hypotheses presented above. For instance, a high income country presumably faces no barriers to invest at home, but simultaneously may not find larger returns domestically relative to abroad. Such countries are already economically and financially integrated with the rest of the world and the additional windfall would require taking into account other aspects besides the intergenerational problem of consumption. Therefore, as long as resource rents are owned by the government, we expect that a high income country will use the opportunity of windfall revenue to set up a well-run SWF. However, it may very well decide to shift the revenue directly or indirectly to its citizens who may save or spend, but in any case will likely not do so through an SWF.

This point may also be related to what is known as Dutch disease, a mechanism through which natural resource exports can under certain conditions appreciate a currency and drive out other export sectors. This mechanism strongly relies on a the 'spending effect' of the export revenues in the domestic economy (Corden and Neary, 1982; Corden, 1984). Therefore, countries worried about this effects may decided to set up an SWF

\footnotetext{
${ }^{9}$ The 'JPMorgan Emerging Markets Bond Index' goes a long way in this respect, but not all rates for the countries included are measured in the same way, and the dataset excludes all non-emerging markets, particularly developed countries.
} 
in order to regulate how much of the revenues can be used over time. However, not all countries may face such issues and a Sovereign Wealth Fund is not the only solution. Open capital markets and labour migration combined with flexible labour markets can significantly accommodate Dutch disease effects (Raveh, 2013; Beine et al., 2014).

Anticipation of a future windfalls, with reserves proven but exploitation still some years off, would induce a preparation period in which a government can borrow to finance consumption and domestic investment today. The borrowing would be reversed to paying of the debt and potentially net savings once the revenues are realised. So an SWF is not necessary set up once revenues are flowing since the revenues are firstly targeted to cover past borrowing. Therefore, the mechanism of anticipation can be indirectly captured by two variables we already discussed. The past debt position as well as past education expenditures may have been occurring exactly in anticipation of future revenues and are predicted to be negatively related to the establishment of an SWF.

Expectations of future commodity price increases, decreasing costs of extraction may also lead to decreasing or even negative savings (van der Ploeg, 2010a). We cannot test the relevance of these aspects for two reasons. Firstly, future commodity prices are presumably set at the world market and thus shared by all countries. The lack of variation between the countries will then not allow us to observe this effect. Decreasing costs of extraction could be varying by country, in the case it depends on local geography rather than global technology, but to our knowledge there does not exist a reliable measure of this for the full range of countries that we take into account, including ones that have no resources.

In short, we aim to test the five hypotheses set out above, which relate both to economic and political factors in the decision to set up an SWF. However, we acknowledge that some variables that serve to capture the factors may actually be working through multiple mechanisms.

\section{Data and Methodology}

The point of this research is essentially to understand why some countries have an SWF and others not. An SWF may be an indicator of a sensible national savings decision, as often related in the theory discussed above. However, as we will see, the decision to establish an SWF is not as strongly related to what we can observe as a national savings position, i.e. some countries may very well implement savings decision outside the institution of an SWF, while others appear to establish an SWF for appearances only. Since some countries established an SWF and others not, we have a classic binary set-up that can be approached by a logit regression. We exploit the 1998-2008 window, where 20 countries established an SWF, to explore the role of a range of potential determinants, as measured at the beginning of the window (1998, or the average over several years ending 
Figure 1: Establishment of SWFs: the 1998-2008 wave

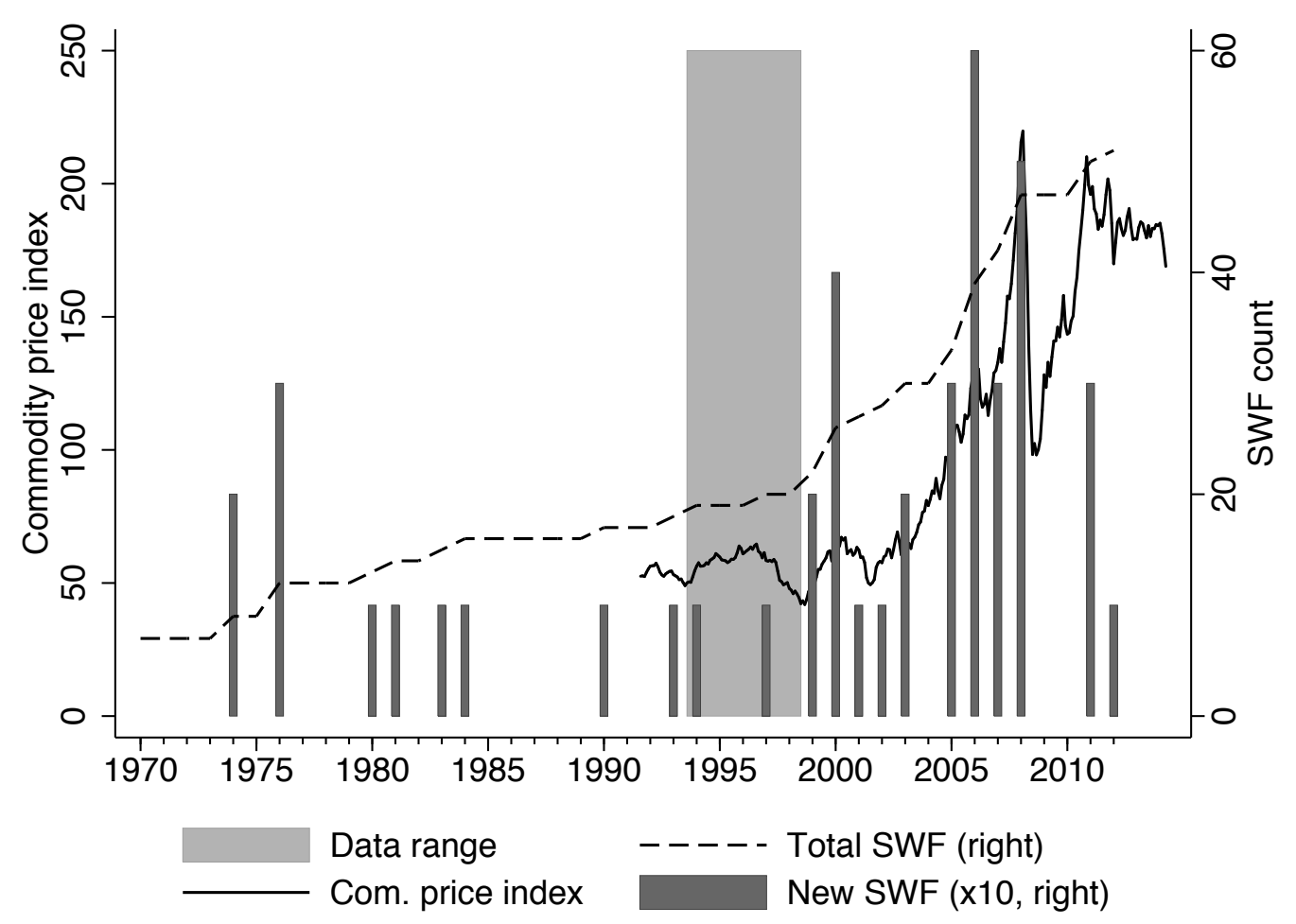

Note: Some countries have set up more than one fund. For representation, the bars indicating the number of new Sovereign Wealth Funds have been multiplied by 10 .

in 1998). ${ }^{10}$

Information on the years of establishment of the SWFs and on the fund management characteristics were collected from Truman (2008). ${ }^{11}$ Since we look at the country level, where necessary we summarise the data over the different funds. For instance, for the establishment data we take the earliest year available, for total funds we take the sum over all the funds. As reported in Table 1, 20 countries set up their first SWF between 1998 and 2008. The largest, whose assets exceed $\$ 100$ billion end of 2013, are China, Qatar, Kazakhstan and Russia. It is striking to note that this 98-08 wave was relatively global, with 2 European, 6 African, 9 Asian and 3 North and South American countries. Our sample of 20 countries includes 32 of the 50 largest funds (as measured in terms of assets at the end of 2013).

Figure 1 plots the number of Sovereign Wealth Funds over time as well as a measure of commodity prices. Starting in 1970, there were seven Sovereign Wealth Funds. During the 1970s through the 1990s every once and a while a new fund was established. We

\footnotetext{
${ }^{10}$ We estimated the models using several window lengths of the past, without much qualitative differences. These results are available on request

${ }^{11}$ And completed by information collected on the website of the Sovereign Wealth Fund Institute, as of 15 January 2014
} 
observe a sharp rise in the frequency that funds were established by the end of the 1990s throughout the first decade of 2000. This pattern coincides with a sharp rise in the price level of many commodities, including oil, metals and agricultural products. The vertical shaded area depicts the time frame from which we draw our independent variables in order to explain the SWFs that were established during 1999-2008. There was a sharp drop in commodity prices around 2008 which again appears to coincide with a sudden stop in new establishments. After 2008, a new boom is observed, which again coincides with new SWF establishments. For this reason we argue that the sudden emergence of many SWF was triggered for a great part by a commodity price boom, which we believe to be exogenous to individual countries. In turn, with the combination of data largely from before the boom, allows us to identify the relevant variables, without necessarily having to control for unobserved heterogeneity.

Since our study focuses on the emergence of SWFs over the 1998-2008 period, we do not include in our study those funds established before 1998. This is on the one hand to establish causation, as the regressors we use are obtained for 1998 or earlier. On the other hand, our discussion on SWFs particularly relates to the emergence of newly established funds, rather than those that have been around for a long time. Nevertheless, results generally continue to hold with the inclusion of the older funds. Additionally, we can reflect to what extent the result for the new funds are in line with the history of the establishment of earlier established funds.

The main funds established before 1998 are reported in Table 2. Our sample does not include the Norwegian SWF (established in 1990 with about US\$818 billion in 2014), The Abu Dhabi Investment Authority SWF (established in 1976 with about $\$ 627$ billion in 2014), the Kuwait Investment Authority (first SWF, established in 1953 with about $\$ 386$ billion in 2014), the Hong-Kong Monetary Authority (established in 1993 with about $\$ 326,7$ billion), The Government of Singapore Investment Corporation (established in 1981 with about $\$ 285$ billion) and Temasek Holdings of Singapore (established in 1974, with $\$ 173,3$ billion).

As suggested in the previous section, the main potential determinants are related to revenue inflows, typically natural resource rents (oil, gas, metals, phosphates), measured in percentage of GDP. We also need to control for the political institutions. We do so by creating an indicator variable equal to 1 if the value of polity2 democracy score is between -10 and 0 (more autocratic), and 0 if the score is above 0 (more democratic) (Marshall et al., 2006). Many oil-exporting countries fall in the autocratic regime category, but note that our sample is not focused on oil and gas, but all commodities. This interaction between resource rents and a country governance structure is discussed in the literature and we look whether we can find a relation of this in the data by including an interaction term between the polity 2 dummy variable and the natural resource rents variable. 
Table 1: Countries with first SWF established in the 1998-2008 wave

\begin{tabular}{|c|c|c|c|c|}
\hline Country & Year & Pension & Assets & Name \\
\hline Algeria & 2000 & No & 77.2 & Revenue Regulation Fund \\
\hline Australia & 2006 & Yes & 88.7 & Australian Future Fund \\
\hline Azerbaijan & 1999 & No & 34.1 & State Oil Fund \\
\hline Chile & 2006 & No & 22.2 & $\begin{array}{l}\text { Social and Economic Stabilization } \\
\text { Fund (15.2). Pension Reserve Fund } \\
(7)\end{array}$ \\
\hline China & 2000 & No & 735.8 & $\begin{array}{l}\text { China Investment Corporation } \\
(575.2) \text {. National Social Security } \\
\text { Fund }(160.6)\end{array}$ \\
\hline France & 2008 & Yes & 25.5 & Strategic Investment Fund \\
\hline Gabon & 1998 & No & 0.4 & Gabon Sovereign Wealth Fund \\
\hline Iran & 2000 & No & 54 & Oil Stabilization Fund \\
\hline Ireland & 2001 & Yes & 19.4 & National Pensions Reserve Fund \\
\hline Kazakhstan & 2000 & No & 166.4 & $\begin{array}{l}\text { Samruk-Kazyna JSC }(77,5) \text {, Kaza- } \\
\text { khstan National Fund }(68,9) \text {, Na- } \\
\text { tional Investment Corporation }(20)\end{array}$ \\
\hline Korea & 2005 & No & 56.6 & Korea Investment Corporation \\
\hline Libya & 2006 & No & 65 & Libyan Investment Authority \\
\hline Mexico & 2000 & No & 6 & $\begin{array}{l}\text { Oil Revenues Stabilization Fund of } \\
\text { Mexico }\end{array}$ \\
\hline New Zealand & 2003 & Yes & 19.3 & NZ Superannuation Fund \\
\hline Nigeria & 2003 & No & 1 & Excess Crude Account \\
\hline Qatar & 2005 & No & 170 & Qatar Investment Authority \\
\hline Russia & 2008 & No & 187.4 & $\begin{array}{l}\text { National Welfare Fund (88), Re- } \\
\text { serve Fund }(86,4) \text {, Russian Direct } \\
\text { Investment Fund (13) }\end{array}$ \\
\hline Sudan & 2002 & No & . & Oil Revenue Stabilization Account \\
\hline Trinidad and Tobago & 2007 & No & 5 & Heritage and Stabilization Fund \\
\hline Venezuela & 1998 & No & . & $\begin{array}{l}\text { National Development Fund, Mac- } \\
\text { roeconomic Stabilization Fund }\end{array}$ \\
\hline
\end{tabular}

Note: We do not consider the date of establishment of the SAFE for China as reference date for the country, since it mostly acted a passive manager of foreign exchange reserves until 2000. Same justification for SAMA in Saudi Arabia. The column "Year" refers to the date of establishment of the SWFs. The Yes in the column "Pension" stands for Pension assets with a weight superior to $50 \%$ of the total country funds (based on Truman (2008)). The column "Assets" reports (cumulated) country assets size in billion US\$ 
Table 2: Top-10 SWFs by assets not included in our sample (establisment before 1998)

\begin{tabular}{|c|c|c|c|c|}
\hline Rank & Country & SWF & Assets & Year \\
\hline 1 & Norway & Government Pension Fund - Global & 818 & 1990 \\
\hline 3 & Abu Dhabi & Abu Dhabi Investment Authority & 627 & 1976 \\
\hline 6 & Kuwait & Kuwait Investment authority & 386 & 1953 \\
\hline 7 & Hong-Kong & HK Monetary Authority & 326.7 & 1993 \\
\hline 8 & Singapore & $\begin{array}{l}\text { Government Singapore Investment } \\
\text { Corp. }\end{array}$ & 285 & 1981 \\
\hline 9 & Singapore & Temasek Holdings & 173.3 & 1974 \\
\hline \multicolumn{5}{|c|}{$\begin{array}{l}\text { Note: The "Rank" and "Assets" columns refer to the ranking and assets (in million US\$) of } \\
\text { the SWFs according to the www.swfinstitute.org ranking, as of December 2013. The column } \\
\text { "Year" refers to the date of establishment of the SWFs. The swfinstitute.org ranking also lists } \\
\text { the Saudi Arabian SAMA and Chinese SAFE as top ten SWFs. These SWFs existed before } \\
\text { 1998, but were acting as passive managers of the foreign exchange reserves. They only switched } \\
\text { to a more active asset management (and only "deserve" the label SWF) after 1998. }\end{array}$} \\
\hline
\end{tabular}

Our theoretical considerations above suggest that SWFs are more likely to get established in those countries that cannot use these funds profitably at home. Although return on investment in capital scarce countries ought to be high, the risk profile and barriers make actual investments difficult. We thus look at two variables that may proxy for this factor: a measure of education spending and a measure of general government expenditures, both expressed in \% of GDP. Having sizeable education expenditures should indicate the ability of a government to invest in public capital domestically, firstly through public education, but it could very well indicate a broader ability for domestic public investments, such as infrastructure. The attention that has historically been given to the role of education in development makes that international comparable data on education expenditures is now available for most countries, as opposed to spending on other types of public capital. We finally also include the log of GDP per capita to control for the general income level of the country.

We define the left-hand side variable as a country dummy equal to 1 if the country established a first SWF in the 1998-2008 window and to 0 otherwise. ${ }^{12}$ The variables on the right-hand side are the potential determinants of the emergence of SWFs, as measured at the very beginning of the window. To mitigate a year-specific effect, we computed the determinants as 5-year averages over 1994-1998 (similarly to Aizenman and Glick, 2009). ${ }^{13}$ In Table 3 descriptive statistics of the main variables that we use are presented, divided over countries that do not set up a fund in the period of analysis versus those that do. ${ }^{14}$

\footnotetext{
${ }^{12}$ Note that Aizenman and Glick (2009) do not define their dummy the same way. They define the country dummy as equal to 1 if an SWF exists in 2007/2008, independently of the date of establishment. Their focus is not precisely on the emergence of SWFs.

${ }^{13}$ Taking the average will also help to full in some gabs of missing data, allowing to increase the sample. This is especially relevant for models that include data on government expenditures.

${ }^{14}$ Table A-2 in the Appendix describes in more details each variable and its source.
} 
Table 3: Descriptive statistics

\begin{tabular}{lrrr|rrrr}
\hline & \multicolumn{3}{c}{ Non-SWF countries } & \multicolumn{1}{c}{ (future) SWF countries } \\
Variable & obs & mean & \multicolumn{1}{c}{ st. dev } & obs & \multicolumn{1}{c}{ mean } & \multicolumn{1}{c}{ st. dev } & equal \\
\hline 1 (Polity2<0) & 144 & 0.31 & 0.46 & 16 & 0.50 & 0.52 & 0.17 \\
Resource rents (\% GDP) & 144 & 6.75 & 11.55 & 16 & 17.45 & 13.93 & 0.01 \\
Comm. Ex. (\% Trade) & 134 & 50.51 & 28.00 & 16 & 67.37 & 29.23 & 0.04 \\
Log GDP/cap. & 144 & 8.50 & 1.16 & 16 & 9.11 & 0.83 & 0.01 \\
Edu. exp. (\% GDP) & 108 & 4.57 & 4.26 & 11 & 3.49 & 0.81 & 0.03 \\
Gov. cons. (\% GDP) & 133 & 16.23 & 6.52 & 16 & 13.18 & 3.73 & 0.01 \\
Curr. acc. (\% GDP) & 127 & -5.27 & 8.34 & 15 & -2.53 & 7.04 & 0.00 \\
Debt (\% GDP) & 132 & 75.36 & 57.54 & 16 & 53.43 & 53.14 & 0.18 \\
NFA (\% GDP) & 131 & -0.74 & 2.19 & 16 & -0.45 & 0.66 & 0.14 \\
FX res. (\% GDP) & 132 & 0.11 & 0.09 & 16 & 0.09 & 0.06 & 0.26 \\
$\sigma^{2}$ (GDP) & 144 & 0.36 & 0.15 & 16 & 0.36 & 0.19 & 0.43 \\
$\sigma^{2}$ (Resource rents) & 133 & 0.53 & 0.46 & 16 & 0.55 & 0.53 & 0.91 \\
\hline
\end{tabular}

Note: Non-SWF countries are those countries that do not have and do not establish a fund before 2008, future SWF countries are those that have no SWF before 1998 but do establish one in 19992008. The last column indicates the $p$-value of a $t$-test on the equality of means. 1 (Polity $2<0$ ) is an indicator variable, Comm. EX. is the commodity exports, Edu. exp. is education expenditures, Gov. cons. is government consumption, curr. acc. is current account, NFA is net financial assets, FX res is foreign exchange reserves, $\sigma^{2}$ (GDP) is the standard deviation of GDP per capita over 1978-1998, $\sigma^{2}$ (Resource rents) is same measure for resource rents. For more data details see Table A-2.

We find that future SWF appear to differ significantly from non-SWF countries in some of the main variables that we use to test our hypothesis, except for regime type, debt, assets and volatility.

To summarise, we include in our benchmark regressions, natural resource rents, government expenditures (as collected from the World Bank Statistics database and expressed in 1994-1998 averages) and a dummy based on the polity2 measure on autocracy-democracy.

The benchmark estimating equation can be represented as follows

$$
S W F_{i}=\operatorname{logit}\left(\beta_{1} \text { Rents }_{i}+\beta_{2} \log \left(G D P p c_{i}\right)+\beta_{3} \text { Non-democrat }_{i}+\beta_{4} \text { GovExp }_{i}\right)+u_{i}
$$

where $S W F_{i}$ represents a dummy of having established an SWF in the period 1998-2008, while the other regressors indicate past country characteristics that have preceded this decision. We will vary the exact combination and form of the right hand side variables. Note that the four independent variables correspond to the hypotheses 1, 2, and 3 defined above. We include $\log \left(G D P p c_{i}\right)$ as a general control variable for a country's development. For each regression we will indicate the number of SWFs in the sample, the Pseudo- $\mathrm{R}^{2}$ and the log-likelihood.

Given that we allow for the establishment of an SWF in a 10-year period, those established early in this period may have a stronger relation to economic and other variables during the 1994-1998 period than those that are established 10 years later. Additionally, 
there is a great heterogeneity between funds, whereby some funds appear to be established for symbolic reasons only as they hold very little assets, while others rank among the biggest in the world. The binary variable for existence is therefore a rather crude measure.

However, alternative setups may have even greater drawbacks. One alternative is to shorten the window of establishments, for instance by taking only 3 or 5 years since 1998 . This would reduce the number of observed positives, and thus a much narrower scope for the interpretation of the results. Alternatively, a panel setup is possible, whereby past data relates to the set-up of a fund in any time. However, this is not appropriate for our dataset and the question we aim to answer, since a conditional logic estimations (a method to substitute out country fixed determinants) can only exploit information from those countries that change from having no fund to having one somewhere during the time-span we analyse. Therefore this estimator is unable to compare those countries that set-up a fund with those that do not. ${ }^{15}$

\section{Results}

The regressions reported in Table 4 lead to three observations. First, a country must be rich (log GDP per capital positive and significant) or have natural resource rents (positive and significant) to establish an SWF (being rich with resources also works naturally). Unsurprisingly, funding matters. Second, the level of education spending and of general government consumption affect negatively the probability of establishing an SWF. This confirms what was suggested by theory; higher domestic level of investment make future domestic investments more profitable and thereby increase the opportunity cost of establishing an SWF. Finally, political regime matters. Autocratic countries are more likely to establish an SWF than democratic ones. In addition, the interaction term between the dummy for autocratic power and natural resource rents is significant, negative and of an amplitude close to the coefficient on the natural resource rent variable. The interpretation is that the role of natural resource is zero for autocratic countries. In other words, natural resources only matter in democratic countries. Autocratic countries tend to establish SWFs, irrespective of actual need to do so. ${ }^{16}$

In economic theory one can make a distinction between government consumption and domestic investment. In reality it is not easy to observe the difference. For instance, expenditures on eduction are clearly government spending that can be counted as consumption, but count as investment for long-term growth in our interpretation. In

\footnotetext{
${ }^{15}$ In addition, the conditional logic depends on a binary variable that is conditionally uncorrelated over time. This is certainly violated in our dataset since countries typically do not wind down a fund but keep it for the remainder of the foreseeable future.

${ }^{16}$ Table B-2 in the appendix gives results for interaction of rents with the other variables. These results indicate that the interaction with regime type is indeed the most important, and results cannot be attributed to some general non-linearity of the rents data.
} 
Table 4: Benchmark

\begin{tabular}{|c|c|c|c|c|c|c|}
\hline & $\begin{array}{c}(1) \\
\text { swf }\end{array}$ & $\begin{array}{c}(2) \\
\text { swf }\end{array}$ & $\begin{array}{c}(3) \\
\text { swf }\end{array}$ & $\begin{array}{c}(4) \\
\text { swf }\end{array}$ & $\begin{array}{c}(5) \\
\text { swf } \\
\end{array}$ & $\begin{array}{c}(6) \\
\text { swf }\end{array}$ \\
\hline Rents (\%GDP) & $\begin{array}{l}0.052^{*} \\
(0.027)\end{array}$ & $\begin{array}{c}0.223^{* * *} \\
(0.053)\end{array}$ & $\begin{array}{c}0.269^{* * *} \\
(0.064)\end{array}$ & $\begin{array}{c}0.262^{* * *} \\
(0.058)\end{array}$ & $\begin{array}{c}0.252^{* * *} \\
(0.066)\end{array}$ & $\begin{array}{c}0.245^{* * *} \\
(0.061)\end{array}$ \\
\hline Log GDPpc & $\begin{array}{c}0.953^{* * *} \\
(0.213)\end{array}$ & $\begin{array}{c}1.403^{* * *} \\
(0.311)\end{array}$ & $\begin{array}{c}1.714^{* * *} \\
(0.421)\end{array}$ & $\begin{array}{c}1.954^{* * *} \\
(0.390)\end{array}$ & $\begin{array}{c}1.458^{* * *} \\
(0.410)\end{array}$ & $\begin{array}{c}1.756^{* * *} \\
(0.438)\end{array}$ \\
\hline Non-democrat & $\begin{array}{c}1.009 \\
(0.852)\end{array}$ & $\begin{array}{c}3.237^{* * * *} \\
(0.959)\end{array}$ & $\begin{array}{l}3.608^{* *} \\
(1.496)\end{array}$ & $\begin{array}{c}3.926^{* * *} \\
(1.172)\end{array}$ & $\begin{array}{c}2.601^{* *} \\
(1.262)\end{array}$ & $\begin{array}{l}3.279^{*} \\
(1.782)\end{array}$ \\
\hline Non-democrat $\times$ Rents & & $\begin{array}{c}-0.203^{* * *} \\
(0.057)\end{array}$ & $\begin{array}{c}-0.264^{* * * *} \\
(0.075)\end{array}$ & $\begin{array}{c}-0.241^{* * *} \\
(0.066)\end{array}$ & $\begin{array}{c}-0.219^{* * *} \\
(0.072)\end{array}$ & $\begin{array}{c}-0.222^{* * *} \\
(0.082)\end{array}$ \\
\hline Edu. exp. & & & $\begin{array}{c}-0.630^{* *} \\
(0.261)\end{array}$ & & & $\begin{array}{l}-0.509 \\
(0.422)\end{array}$ \\
\hline Gov. cons. & & & & $\begin{array}{c}-0.249 * * * \\
(0.071)\end{array}$ & & \\
\hline Gov. exp. excl. edu. & & & & & $\begin{array}{c}-0.073^{*} \\
(0.043)\end{array}$ & $\begin{array}{l}-0.198 \\
(0.123)\end{array}$ \\
\hline Constant & $\begin{array}{c}-11.552^{* * *} \\
(2.125)\end{array}$ & $\begin{array}{c}-16.846^{* * *} \\
(3.292)\end{array}$ & $\begin{array}{c}-17.431^{* * *} \\
(4.084)\end{array}$ & $\begin{array}{c}-18.468^{* * *} \\
(3.545)\end{array}$ & $\begin{array}{c}-16.461^{* * *} \\
(4.284)\end{array}$ & $\begin{array}{c}-16.037^{* * *} \\
(3.828)\end{array}$ \\
\hline Observations & 160 & 160 & 119 & 149 & 115 & 115 \\
\hline n. SWFs & 16 & 16 & 11 & 16 & 11 & 11 \\
\hline Pseudo $\mathrm{R}^{2}$ & 0.18 & 0.32 & 0.37 & 0.42 & 0.34 & 0.42 \\
\hline 11 & -42.57 & -35.63 & -22.98 & -29.66 & -24.04 & -20.89 \\
\hline
\end{tabular}

Robust standard errors in parentheses

*** $\mathrm{p}<0.01,{ }^{* *} \mathrm{p}<0.05,{ }^{*} \mathrm{p}<0.1$ 
contrast, there might be plenty of government expenditures that we should interpret as (wasteful) consumption rather than genuine attempts for long-term growth. This may include extending the public sector for patronage reasons, expenditures on luxury goods for government officials etc. On the other hand, money can only be spent once. Therefore, any government expenditures will decrease the amount available for savings. The negative coefficient fits both the story of current consumption and long-term investments. The question then is whether we can disentangle the two mechanisms.

In our dataset, there is more data available for the general government account than the more specific educational expenditures or even other part of the government budget. In the model, individually both relate negatively to the establishment of SWFs (models 3 and 4), but their coefficients differ, with past educational expenditures indicating a stronger negative effect on the probability of setting up an SWF compared to government consumption. Government expenditures include already the expenditures on education. When we include government expenditures excluding education we find a smaller and less significant coefficient. When we include both education and other government expenditures both are individual insignificant, but an F-test on the two coefficients to be jointly zero is rejected at $1 \%$ ( $p$-value is 0.004 ), indicating that there is still some correlation among the two indicators. This further confirms our hypothesis that SWFs may be the result of the lack or unwillingness to invest domestically in a new economy. ${ }^{17}$

In order to understand the size of the effects we estimate marginal effects for model 3 over several cases. Table 5 presents the results. The first column gives the result of a linear probability model (LPM) using the same sample and model as the other columns, but presenting only the relevant coefficients. Column two gives the figures for the average marginal effect over the sample using the logit. These coefficients can be interpreted as the effect of a unit change of $x$ on the probability of observing an SWF, similar to the coefficients of the LPM. For instance, an increase of resource rents by $1 \%$ would increase the probability of observing an SWF by $0.85 \%$. This is a sizeable effect for those countries that experience a significant boom. The income figure implies that rising income per capita strongly increases the probability of observing a fund, which underlines that a fund is principally a savings instrument. The coefficient on expenditure on education indicates that a $1 \%$ increase in educational expenditures decreases the probability of observing an SWF in the future. These two factors, income and education, underline the opposing effects of saving due to increased income and domestic investment for the benefit of economic development. Relative to the LPM, the estimated effects from the

\footnotetext{
${ }^{17}$ The availability of data cannot be assumed to be completely random in this case. Data on educational expenditures is much scarcer. Those countries that produce such data are probably more likely to value such figures, independent of the actual value, implying that there exist already a certain mechanism for proper government spending. Countries with regimes that aim to hide as much as possible where government money is spent would drop out of the sample.
} 
Table 5: Marginal Effects

\begin{tabular}{lcccc}
\hline & $(1)$ & $(2)$ & $(3)$ & $(4)$ \\
& LPM & AME & democrat. & non-democrat. \\
\hline Rents & $2.83^{* * *}$ & $0.85^{* * *}$ & $1.17^{* * *}$ & 0.00 \\
& $(0.64)$ & $(0.25)$ & $(0.33)$ & $(0.22)$ \\
log GDPpc & $10.35^{* * *}$ & $9.11^{* * *}$ & $7.47^{* * *}$ & $13.39^{* * *}$ \\
& $(2.22)$ & $(2.42)$ & $(2.62)$ & $(4.94)$ \\
Edu. exp. & -0.55 & $-3.35^{* *}$ & $-2.75^{*}$ & $-4.92^{*}$ \\
& $(0.38)$ & $(1.70)$ & $(1.53)$ & $(2.80)$ \\
\hline
\end{tabular}

Note: LPM is linear probability model on the same set of variables. The other columns are based on the model in Table 4, model 3. AME: Average Marginal Effect.

logic model of rents is smaller, while that on education bigger, but the magnitude and sign are broadly in line.

In columns 3 and 4 we compare the coefficients over democratic and non-democratic governments. This comparison allows to show the interactive effect that this government characteristic has on all the determinants due to the non-constant marginal effects the logit model. The marginal effects for democratic governments are very similar to the average marginal effects, although the effect of resource rents is slightly decreased, while for income it is slightly increased. For non-democratic countries however the marginal effects are very different. The estimates indicate that resource rents are not related to the establishment of a fund, in line with the observation in Table 4. Apparently there are enough countries in the sample that establish a fund while our data indicates that their rents are only marginal in period before. ${ }^{18}$ Income per capita still has a significant coefficient. The effect on resource rents disappears in line with the observation in Table 4. The estimate for educational expenditures is larger compared to democratic regimes indicating that the trade-off between public expenditures or savings is much stronger in autocratic regimes relative to democratic countries.

Starting from these benchmark results we explore the sample in five directions. Firstly, we will look at alternative regressors on top of our benchmark regression, including those that belong to Hypotheses 4 and 5 (the roles of debt and uncertainty respectively). Secondly, we look at some alternative measures for the independent variables. Thirdly, we try to explore through which channel the political factor affects the decision. Fourthly, we change the dependent variable from the binary indicator to variables indicating the asset position of a country. This will allow us to understand further to what extent an SWF is

\footnotetext{
${ }^{18}$ This could also be because some countries were forward looking, setting up a fund before the rents started flowing
} 
a function of economic-financial variables. Finally, we use duration analysis, which asks a slightly different question but offers strikingly consistent results.

AppendixB offers some further robustness results with alternative estimations. For instance, Table B-1 explores the possibility that log GDP per capita and education are not linear in the model, but perhaps reverse sign dependent on their level. There is some evidence that the effect of log GDP per capita follows a inverse-U shape. The shape would suggest that both the very poor and very rich are less likely to set up a fund, which goes counter the predictions of the theoretical models. The effect of education is similarly inverse-U shaped, changing sign at 3\% of GDP, suggesting that too low education expenditures would induce an SWF, but that around the mean (around $4 \%$ in the sample) countries appear to be more likely to invest in education (and potentially other investments correlated with it), then to save proceeds in an SWF. Table B-5 and Figure B-1 explore whether the results are driven by sample selection or outliers, Table B-5 through a constant sample setup of the benchmark model and Figure B-1 through a exclusion of a single observation. The main results are fully supported.

\subsection{Alternative regressors}

Table 6 explores the role of a complementary set of regressors. We first introduce two new proxies for the funding of SWFs, namely the current account balance, stock of government debt, the net financial assets (NFA) and the foreign exchange reserves (FXRes). As different measures for economic surpluses, we expect current account surpluses and large positive net financial assets to be positively correlated to the probability of setting up an SWF, while debt should be negatively correlated corresponding to Hypothesis 4. We then also include a measure for economic risk, corresponding to Hypothesis 5. We use the 20-years standard deviation of GDP per capita, $\sigma^{2}$ (GDP), and the 20-years standard deviation of natural resource rents, $\sigma^{2}$ (Rents), as proxies for the future uncertainty. ${ }^{19}$ Volatility in the economy or from the resource rents would work as an incentive to additional precautionary saving. In order to achieve the most stable income stream from volatile receipts safe foreign investments would be related positively to setting up an SWF, rather than absorb such flows in the domestic economy. However, volatility might also give scope to abuse as changing prices and production give opportunity for back-channelling receipts to those in power. ${ }^{20}$

We find in Table 6 that these additional regressors do not bring much to the benchmark model. They are mostly not statistically significant, meaning that natural resource rents and log GDP per capita are sufficient to capture the funding component, and that

\footnotetext{
${ }^{19}$ We experimented with shorter samples, which give qualitatively similar results.

${ }^{20}$ Ideally, we may wish to use more recent measures of volatility or even of expected volatility as a better measure for uncertainty. As of yet we have no such measures available. In contrast, 20 years past data should give a very conservative estimate for this uncertainty measure.
} 
Table 6: Alternative regressors

\begin{tabular}{|c|c|c|c|c|c|c|}
\hline & $\begin{array}{l}(1) \\
\text { swf }\end{array}$ & $\begin{array}{l}(2) \\
\text { swf }\end{array}$ & $\begin{array}{c}(3) \\
\text { swf }\end{array}$ & $\begin{array}{l}(4) \\
\text { swf }\end{array}$ & $\begin{array}{l}(5) \\
\text { swf }\end{array}$ & $\begin{array}{c}(6) \\
\text { swf }\end{array}$ \\
\hline Rents (\%GDP) & $\begin{array}{c}0.207^{* * * *} \\
(0.053)\end{array}$ & $\begin{array}{c}0.217^{* * * *} \\
(0.056)\end{array}$ & $\begin{array}{c}0.218^{* * *} \\
(0.052)\end{array}$ & $\begin{array}{c}0.218^{* * *} \\
(0.053)\end{array}$ & $\begin{array}{c}0.253^{* * *} \\
(0.065)\end{array}$ & $\begin{array}{c}0.218^{* * *} \\
(0.053)\end{array}$ \\
\hline Log GDPpc & $\begin{array}{c}1.299^{* * *} \\
(0.310)\end{array}$ & $\begin{array}{c}1.326^{* * *} \\
(0.337)\end{array}$ & $\begin{array}{c}1.520^{* * *} \\
(0.348)\end{array}$ & $\begin{array}{c}1.479 * * * \\
(0.314)\end{array}$ & $\begin{array}{c}1.431^{* * *} \\
(0.327)\end{array}$ & $\begin{array}{c}1.399^{* * *} \\
(0.360)\end{array}$ \\
\hline Non-democrat & $\begin{array}{c}2.976^{* * *} \\
(1.006)\end{array}$ & $\begin{array}{c}3.123^{* * *} \\
(1.049)\end{array}$ & $\begin{array}{c}3.276^{* * *} \\
(1.036)\end{array}$ & $\begin{array}{c}3.384^{* * *} \\
(1.053)\end{array}$ & $\begin{array}{c}3.748^{* * *} \\
(0.960)\end{array}$ & $\begin{array}{c}3.106^{* * *} \\
(0.973)\end{array}$ \\
\hline Non-democrat $\times$ Rents & $\begin{array}{c}-0.181^{* * *} \\
(0.060)\end{array}$ & $\begin{array}{c}-0.188^{* * * *} \\
(0.065)\end{array}$ & $\begin{array}{c}-0.199 * * * \\
(0.058)\end{array}$ & $\begin{array}{c}-0.202^{* * *} \\
(0.058)\end{array}$ & $\begin{array}{c}-0.236^{* * *} \\
(0.066)\end{array}$ & $\begin{array}{c}-0.197 * * * \\
(0.057)\end{array}$ \\
\hline Curr. Acc. ( $\%$ GDP) & $\begin{array}{c}0.020 \\
(0.030)\end{array}$ & & & & & \\
\hline DebtGDP & & $\begin{array}{l}-0.010 \\
(0.014)\end{array}$ & & & & \\
\hline NFA & & & $\begin{array}{c}0.060 \\
(0.476)\end{array}$ & & & \\
\hline FXRes (\% GDP) & & & & $\begin{array}{l}-3.239 \\
(3.450)\end{array}$ & & \\
\hline$\sigma^{2}(\mathrm{GDP})$ & & & & & $\begin{array}{c}2.876 \\
(2.605)\end{array}$ & \\
\hline$\sigma^{2}$ (Rents) & & & & & & $\begin{array}{c}0.131 \\
(0.602)\end{array}$ \\
\hline Constant & $\begin{array}{c}-15.630 * * * \\
(3.252)\end{array}$ & $\begin{array}{c}-15.409 * * * \\
(3.663)\end{array}$ & $\begin{array}{c}-17.728^{* * *} \\
(3.627)\end{array}$ & $\begin{array}{c}-17.121^{* * *} \\
(3.289)\end{array}$ & $\begin{array}{c}-18.462^{* * *} \\
(3.420)\end{array}$ & $\begin{array}{c}-16.749 * * * \\
(3.456)\end{array}$ \\
\hline Observations & 142 & 148 & 147 & 148 & 160 & 149 \\
\hline n. SWFs & 15 & 16 & 16 & 16 & 16 & 16 \\
\hline Pseudo $\mathrm{R}^{2}$ & 0.31 & 0.33 & 0.32 & 0.32 & 0.33 & 0.31 \\
\hline 11 & -33.19 & -33.74 & -34.29 & -34.28 & -34.68 & -35.03 \\
\hline
\end{tabular}

Robust standard errors in parentheses

$* * * \mathrm{p}<0.01, * * \mathrm{p}<0.05, * \mathrm{p}<0.1$

uncertainty plays no clear role on the emergence of SWFs in the sample. ${ }^{21}$ Surprisingly, the debt stock appears to play no general role in the prediction for an SWF. ${ }^{22}$

Finally, we may suspect that income per capita will not capture to what extent this income is spread over the entire population, whereas oil rents are often concentrated towards an elite. Hence, we may suspect that in societies where income or wealth is more unequally distributed are more likely to set up an SWF as the elite will make this decision for themselves rather than for the people. Alternatively, one may expect that more equal societies may indicate better economic institutions that would induce

\footnotetext{
${ }^{21}$ Other variables were included of which results are not presented, such as household consumption as precentage of GDP (in case there is a trade off between government and private household spending and savings, as well as gross savings as a percentage of GDP. Neither were significant nor affected the other variables. Table B-3 presents the same models in the extended benchmark model that includes general government and education expenditures. The conclusions do not change materially

${ }^{22}$ Table B-4 in the appendix presents further results with respect to the debt variable. We find that only in a more limited sample is debt able to predict the probability of an SWF.
} 
Table 7: Alternative regressors based on Gini Index

\begin{tabular}{|c|c|c|c|c|}
\hline & $\begin{array}{c}(1) \\
\text { reduced sample } \\
\text { swf }\end{array}$ & $\begin{array}{l}\text { (2) } \\
\text { swf } \\
\end{array}$ & $\begin{array}{l}(3) \\
\text { swf }\end{array}$ & $\begin{array}{l}(4) \\
\text { swf } \\
\end{array}$ \\
\hline Rents (\%GDP) & $\begin{array}{c}0.236^{* * *} \\
(0.068)\end{array}$ & $\begin{array}{c}0.227^{* * *} \\
(0.065)\end{array}$ & $\begin{array}{c}0.229^{* * *} \\
(0.065)\end{array}$ & $\begin{array}{c}0.235^{* * *} \\
(0.068)\end{array}$ \\
\hline Log GDPpc & $\begin{array}{c}2.060^{* * *} \\
(0.689)\end{array}$ & $\begin{array}{c}2.337^{* * *} \\
(0.847)\end{array}$ & $\begin{array}{c}2.282^{* * *} \\
(0.824)\end{array}$ & \\
\hline Non-democrat & $\begin{array}{c}3.015^{* *} \\
(1.307)\end{array}$ & $\begin{array}{c}3.617^{* * *} \\
(1.281)\end{array}$ & $\begin{array}{c}3.507^{* * *} \\
(1.268)\end{array}$ & $\begin{array}{c}3.419^{* * *} \\
(1.280)\end{array}$ \\
\hline Non-democrat $\times$ Rents & $\begin{array}{c}-0.177^{* *} \\
(0.081)\end{array}$ & $\begin{array}{c}-0.169^{* *} \\
(0.078)\end{array}$ & $\begin{array}{c}-0.169^{* *} \\
(0.078)\end{array}$ & $\begin{array}{c}-0.175^{* *} \\
(0.079)\end{array}$ \\
\hline Gov. cons. & $\begin{array}{c}-0.190^{* *} \\
(0.085)\end{array}$ & $\begin{array}{c}-0.169^{* *} \\
(0.070)\end{array}$ & $\begin{array}{c}-0.172^{* *} \\
(0.072)\end{array}$ & $\begin{array}{c}-0.182^{* *} \\
(0.075)\end{array}$ \\
\hline Gini index & & $\begin{array}{l}0.069^{*} \\
(0.039)\end{array}$ & & \\
\hline $\log (100-$ Gini $)$ & & & $\begin{array}{l}-3.346 \\
(2.053)\end{array}$ & \\
\hline $\log$ Gini-corrected GDPpc & & & & $\begin{array}{c}2.280^{* * *} \\
(0.813)\end{array}$ \\
\hline Constant & $\begin{array}{c}-19.830 * * * \\
(5.980)\end{array}$ & $\begin{array}{c}-25.701^{* * *} \\
(9.037)\end{array}$ & $\begin{array}{l}-8.682 \\
(6.559)\end{array}$ & $\begin{array}{c}-12.817^{* * *} \\
(4.149)\end{array}$ \\
\hline Observations & 98 & 98 & 98 & 98 \\
\hline n. SWFs & 11 & 11 & 11 & 11 \\
\hline Pseudo $\mathrm{R}^{2}$ & 0.37 & 0.40 & 0.39 & 0.39 \\
\hline 11 & -21.62 & -20.70 & -20.90 & -20.98 \\
\hline
\end{tabular}

long term planning, among which an SWF. Table 7 shows that inequality -as measured by the GINI-coefficient- seems to play no role. Part of the explanation for the lack of explanatory power of the Gini coefficient and of Gini-adjusted GDP per capita measures may be due to the reduced sample, whereby predominantly the most unequal societies drop out of the sample for lack of data. Still, given that the other variables remain robustly significant lead us to conclude that we have no evidence that income inequality improves our understanding of the establishment of SWFs.

\subsection{Alternative measures}

We present some alternatives in the measures of the rents in Table 8. The World Bank provides figures for oil and gas separately. We find that the mechanism holds for both types of rents, but is stronger for natural gas. The sample size is greatly reduced for this measure, nonetheless the estimates are very much in line with the main results. For models (2) and (4) a joint-test on the coefficients on Government expenditures excluding education and education expenditures give $p$-values of 0.020 and 0.001 respectively, fully supporting the benchmark result.

Additionally, we created our own resource wealth measure based on trade statistics, 
Table 8: Alternative resource measures

\begin{tabular}{|c|c|c|c|c|c|c|}
\hline & $\begin{array}{l}1) \\
\text { swf }\end{array}$ & $\begin{array}{l}(2) \\
\text { swf }\end{array}$ & $\begin{array}{l}(3) \\
\text { swf }\end{array}$ & $\begin{array}{l}(4) \\
\text { swf }\end{array}$ & $\begin{array}{l}(5) \\
\text { swf }\end{array}$ & $\begin{array}{l}(6) \\
\text { swf }\end{array}$ \\
\hline Natural Gas Rents & $\begin{array}{c}1.077^{* * * *} \\
(0.333)\end{array}$ & $\begin{array}{c}1.093^{* *} \\
(0.447)\end{array}$ & & & & \\
\hline Oil Rents & & & $\begin{array}{c}0.447^{* * *} \\
(0.130)\end{array}$ & $\begin{array}{c}0.366^{* *} \\
(0.150)\end{array}$ & & \\
\hline Commodity Ex. & & & & & $\begin{array}{c}0.040^{* *} \\
(0.018)\end{array}$ & $\begin{array}{c}0.040^{* *} \\
(0.019)\end{array}$ \\
\hline Log GDPpc & $\begin{array}{c}0.914^{* * *} \\
(0.295)\end{array}$ & $\begin{array}{c}1.433^{* * *} \\
(0.456)\end{array}$ & $\begin{array}{c}0.935^{* * *} \\
(0.320)\end{array}$ & $\begin{array}{c}1.250^{* * *} \\
(0.447)\end{array}$ & $\begin{array}{c}1.381^{* * *} \\
(0.312)\end{array}$ & $\begin{array}{c}1.860^{* * *} \\
(0.429)\end{array}$ \\
\hline Non-democrat & $\begin{array}{c}2.751^{* * *} \\
(0.869)\end{array}$ & $\begin{array}{c}2.305 \\
(1.484)\end{array}$ & $\begin{array}{c}2.570^{* * *} \\
(0.902)\end{array}$ & $\begin{array}{l}2.443^{*} \\
(1.479)\end{array}$ & $\begin{array}{c}2.459 \\
(2.067)\end{array}$ & $\begin{array}{l}4.910^{*} \\
(2.925)\end{array}$ \\
\hline Non-democrat $\times$ Gas rents & $\begin{array}{c}-1.075^{* * *} \\
(0.335)\end{array}$ & $\begin{array}{l}-0.662 \\
(0.519)\end{array}$ & & & & \\
\hline Non-democrat $\times$ Oil rents & & & $\begin{array}{c}-0.425^{* * *} \\
(0.133)\end{array}$ & $\begin{array}{c}-0.336^{* *} \\
(0.154)\end{array}$ & & \\
\hline Non-democrat $\times$ Com. Exp & & & & & $\begin{array}{l}-0.015 \\
(0.028)\end{array}$ & $\begin{array}{l}-0.050 \\
(0.038)\end{array}$ \\
\hline Gov. exp. excl. edu. & & $\begin{array}{l}-0.189 \\
(0.118)\end{array}$ & & $\begin{array}{c}-0.219^{*} \\
(0.125)\end{array}$ & & $\begin{array}{c}-0.227^{* *} \\
(0.098)\end{array}$ \\
\hline Edu. exp. & & $\begin{array}{l}-0.561 \\
(0.456)\end{array}$ & & $\begin{array}{l}-0.441 \\
(0.381)\end{array}$ & & $\begin{array}{l}-0.471 \\
(0.321)\end{array}$ \\
\hline Constant & $\begin{array}{c}-11.551^{* * *} \\
(3.072)\end{array}$ & $\begin{array}{c}-12.194^{* * *} \\
(3.593)\end{array}$ & $\begin{array}{c}-11.865^{* * *} \\
(3.283)\end{array}$ & $\begin{array}{c}-10.714^{* * *} \\
(3.451)\end{array}$ & $\begin{array}{c}-17.197^{* * *} \\
(3.628)\end{array}$ & $\begin{array}{c}-17.320^{* * *} \\
(3.838)\end{array}$ \\
\hline Observations & 112 & 92 & 113 & 93 & 150 & 111 \\
\hline n. SWFs & 16 & 11 & 16 & 11 & 16 & 11 \\
\hline Pseudo $\mathrm{R}^{2}$ & 0.27 & 0.40 & 0.30 & 0.42 & 0.22 & 0.32 \\
\hline 11 & -33.53 & -20.13 & -32.06 & -19.72 & -39.84 & -24.22 \\
\hline
\end{tabular}


which measures the percentage of primary commodities in total trade. One drawback of the rents measure is that it does not capture whether the resource is used for domestic consumption or mostly exported, while SWFs are often related to exported commodities. We find that the export measure offers consistent results. In a reduced benchmark model, which excludes some government expenditure measures, and has a larger sample size, the regime variable is no longer significant. However, for the larger benchmark model, and the smaller sample, the results are entirely in line with what we found before (a joint-test on government expenditures excluding education and education expenditures gives a $p$-value of 0.014). Nevertheless, the impact of commodity exports is distinctively smaller, and coefficient on the interaction with regime type does not indicate the same relation as we find for the resource rents.

\subsection{Political channels}

Table 9 looks further into the channels of the regime determinants on Sovereign Wealth Fund. We present the regression of the benchmark model while replacing the original non-democratic dummy with measures found in the PolityIV dataset. As documented above, theoretical papers tend to predict that government accountability and property rights are the key channels through which political decision making takes place. In fact, it appears that several of the factors in the PolityIV dataset play a role, in particular factors determining the structure of the highest government position, but also the role of political opposition. We note that for these variables the coefficients on the other variables are hardly affected, showing that the model in general is very robust. (Signs of the coefficients on rents and its interaction are occasionally reversed due to the way the qualitative indicators are measured.)

These findings are in line with the theoretical predictions discussed before, in particular with respect to the extent of government accountability to policies for the long term benefit of the country. The results give further strong evidence that government characteristics are related to the establishment of SWFs. However, not all of the governance measures give statistically significant results, or they strongly affect the coefficients of the other variables. We also looked at various measures on the duration of governments. We expect that one way to capture the future horizon that a ruler considers when making savings and investment decisions is the stability of the regime to date. We failed to find evidence that such duration measures could predict the decision to setup an SWF (not shown).

\subsection{Alternative dependent variable}

In this subsection we aim to further indicate whether the establishment of an SWF is distinct from the financial position of a country. In Table 6 , we already showed that macrofinancial variables (debt, NFA) have hardly any explanatory power for establishment of an SWF. If anything, there may be an intuitive positive contribution. In Table 10 we follow up on this by making the net foreign asset position and the foreign exchange reserves (both 
Table 9: Political Channels

\begin{tabular}{|c|c|c|c|c|c|}
\hline VARIABLES & $\begin{array}{c}(1) \\
\text { nondemocrat1998 } \\
\text { swf }\end{array}$ & $\begin{array}{c}(2) \\
\text { xrreg } \\
\text { swf } \\
\end{array}$ & $\begin{array}{c}(3) \\
\text { xrcomp } \\
\text { swf }\end{array}$ & $\begin{array}{c}(4) \\
\text { xropen } \\
\text { swf }\end{array}$ & $\begin{array}{c}(5) \\
\text { xconst } \\
\text { swf }\end{array}$ \\
\hline Rents (\%GDP) & $\begin{array}{c}0.262^{* * *} \\
(0.058)\end{array}$ & $\begin{array}{c}-0.258^{* *} \\
(0.111)\end{array}$ & $\begin{array}{l}-0.024 \\
(0.041)\end{array}$ & $\begin{array}{c}0.005 \\
(0.032)\end{array}$ & $\begin{array}{l}-0.072 \\
(0.048)\end{array}$ \\
\hline Log GDPpc & $\begin{array}{c}1.954^{* * * *} \\
(0.390)\end{array}$ & $\begin{array}{c}3.129^{* * *} \\
(0.784)\end{array}$ & $\begin{array}{c}2.649^{* * *} * \\
(0.567)\end{array}$ & $\begin{array}{c}1.647^{* * *} \\
(0.480)\end{array}$ & $\begin{array}{c}2.677^{* * *} \\
(0.627)\end{array}$ \\
\hline polity var & $\begin{array}{c}3.926^{* * *} \\
(1.172)\end{array}$ & $\begin{array}{c}-6.425^{* * *} \\
(1.394)\end{array}$ & $\begin{array}{c}-2.453^{* * *} \\
(0.475)\end{array}$ & $\begin{array}{c}-0.793^{* *} \\
(0.340)\end{array}$ & $\begin{array}{c}-1.248^{* * *} \\
(0.289)\end{array}$ \\
\hline polity var $\times$ Rents & $\begin{array}{c}-0.241^{* * *} \\
(0.066)\end{array}$ & $\begin{array}{c}0.156^{* * *} \\
(0.054)\end{array}$ & $\begin{array}{c}0.063^{* * *} \\
(0.024)\end{array}$ & $\begin{array}{c}0.026 \\
(0.020)\end{array}$ & $\begin{array}{c}0.043^{* *} \\
(0.017)\end{array}$ \\
\hline Gov. cons. & $\begin{array}{c}-0.249 * * * \\
(0.071)\end{array}$ & $\begin{array}{c}-0.228^{* * *} \\
(0.074)\end{array}$ & $\begin{array}{c}-0.273^{* * *} \\
(0.082)\end{array}$ & $\begin{array}{c}-0.232^{* * *} \\
(0.076)\end{array}$ & $\begin{array}{c}-0.281^{* * *} \\
(0.089)\end{array}$ \\
\hline Constant & $\begin{array}{c}-18.468^{* * *} \\
(3.545)\end{array}$ & $\begin{array}{c}-12.693^{* * *} \\
(4.563)\end{array}$ & $\begin{array}{c}-17.822^{* * *} \\
(3.879)\end{array}$ & $\begin{array}{c}-11.356^{* * *} \\
(2.976)\end{array}$ & $\begin{array}{c}-16.979 * * * \\
(4.031)\end{array}$ \\
\hline $\begin{array}{l}\text { Observations } \\
\mathrm{n} \text {. SWFs } \\
\text { Pseudo R }{ }^{2} \\
\text { ll }\end{array}$ & $\begin{array}{c}149 \\
16 \\
0.42 \\
-29.66\end{array}$ & $\begin{array}{c}130 \\
16 \\
0.56 \\
-21.27\end{array}$ & $\begin{array}{c}130 \\
16 \\
0.48 \\
-25.25\end{array}$ & $\begin{array}{c}130 \\
16 \\
0.32 \\
-32.74 \\
\end{array}$ & $\begin{array}{c}130 \\
16 \\
0.50 \\
-24.29\end{array}$ \\
\hline VARIABLES & $\begin{array}{c}(6) \\
\text { parreg } \\
\text { swf }\end{array}$ & $\begin{array}{c}(7) \\
\text { parcomp } \\
\text { swf }\end{array}$ & $\begin{array}{c}(8) \\
\text { exrec } \\
\text { swf }\end{array}$ & $\begin{array}{c}(9) \\
\text { exconst } \\
\text { swf }\end{array}$ & $\begin{array}{c}(10) \\
\text { polcomp } \\
\text { swf }\end{array}$ \\
\hline Rents (\%GDP) & $\begin{array}{c}0.155^{* *} \\
(0.074)\end{array}$ & $\begin{array}{c}-0.172^{*} \\
(0.095)\end{array}$ & $\begin{array}{c}-0.062 \\
(0.069)\end{array}$ & $\begin{array}{c}-0.072 \\
(0.048)\end{array}$ & $\begin{array}{c}-0.073 \\
(0.051)\end{array}$ \\
\hline Log GDPpc & $\begin{array}{c}1.519^{* * *} \\
(0.513)\end{array}$ & $\begin{array}{c}3.071^{* * *} \\
(0.665)\end{array}$ & $\begin{array}{c}1.976^{* * *} \\
(0.431)\end{array}$ & $\begin{array}{c}2.677^{* * *} \\
(0.627)\end{array}$ & $\begin{array}{c}2.540^{* * *} \\
(0.547)\end{array}$ \\
\hline polity var & $\begin{array}{l}-0.313 \\
(0.375)\end{array}$ & $\begin{array}{c}-2.228^{* * *} \\
(0.511)\end{array}$ & $\begin{array}{c}-0.771^{* * *} \\
(0.208)\end{array}$ & $\begin{array}{c}-1.248^{* * *} \\
(0.289)\end{array}$ & $\begin{array}{c}-0.732^{* * *} \\
(0.190)\end{array}$ \\
\hline polity var $\times$ Rents & $\begin{array}{c}-0.022 \\
(0.021)\end{array}$ & $\begin{array}{c}0.103^{* * *} \\
(0.040)\end{array}$ & $\begin{array}{c}0.024^{*} \\
(0.013)\end{array}$ & $\begin{array}{c}0.043^{* *} \\
(0.017)\end{array}$ & $\begin{array}{c}0.036^{* * *} \\
(0.013)\end{array}$ \\
\hline Gov. cons. & $\begin{array}{c}-0.212^{* * *} \\
(0.065)\end{array}$ & $\begin{array}{c}-0.278^{* * *} \\
(0.078)\end{array}$ & $\begin{array}{c}-0.276^{* * *} \\
(0.088)\end{array}$ & $\begin{array}{c}-0.281^{* * *} \\
(0.089)\end{array}$ & $\begin{array}{c}-0.267^{* * *} \\
(0.077)\end{array}$ \\
\hline Constant & $\begin{array}{c}-12.299^{* * *} \\
(3.861)\end{array}$ & $\begin{array}{c}-19.279^{* * *} \\
(4.183)\end{array}$ & $\begin{array}{c}-11.621^{* * *} \\
(2.868)\end{array}$ & $\begin{array}{c}-16.979 * * * \\
(4.031)\end{array}$ & $\begin{array}{c}-17.114^{* * *} \\
(3.526)\end{array}$ \\
\hline Observations & 130 & 130 & 130 & 130 & 130 \\
\hline n. SWFs & 16 & 16 & 16 & 16 & 16 \\
\hline Pseudo $\mathrm{R}^{2}$ & 0.30 & 0.51 & 0.39 & 0.50 & 0.48 \\
\hline 11 & -33.82 & -23.77 & -29.41 & -24.29 & -25.41 \\
\hline
\end{tabular}

Robust standard errors in parentheses

*** $\mathrm{p}<0.01, * * \mathrm{p}<0.05,{ }^{*} \mathrm{p}<0.1$

The polity variables indicated at the top of each model are: (2) xrreg: regulation of chief executive recruitment, (3) xrcomp: competitiveness of executive recruitment, (4) xropen: openness of executive recruitment, (5) xconst: executive constraints (decision rules), (6) parreg: regulation of participation, (7) parcomp: the competitiveness of participation, (8) exrec: executive recruitment concept, (9) exconst: executive constraints concept, (10) polcomp political competition concept. See Marshall et al. (2006) for details. 
Table 10: Alternative dependent variable

\begin{tabular}{|c|c|c|c|c|}
\hline VARIABLES & $\begin{array}{c}(1) \\
\text { FXRes }\end{array}$ & $\begin{array}{c}(2) \\
\text { FXRes }\end{array}$ & $\begin{array}{c}(3) \\
\text { NFA }\end{array}$ & $\begin{array}{c}(4) \\
\text { NFA }\end{array}$ \\
\hline Rents (\%GDP) & $\begin{array}{c}-0.000 \\
(0.001)\end{array}$ & $\begin{array}{c}0.001 \\
(0.001)\end{array}$ & $\begin{array}{c}0.013 \\
(0.015)\end{array}$ & $\begin{array}{l}-0.017 \\
(0.011)\end{array}$ \\
\hline Log GDPpc & $\begin{array}{c}0.006 \\
(0.006)\end{array}$ & $\begin{array}{c}0.007 \\
(0.007)\end{array}$ & $\begin{array}{c}0.427^{* *} \\
(0.182)\end{array}$ & $\begin{array}{c}0.119 * * \\
(0.047)\end{array}$ \\
\hline Non-democrat & $\begin{array}{c}0.015 \\
(0.025)\end{array}$ & $\begin{array}{l}0.062^{*} \\
(0.037)\end{array}$ & $\begin{array}{c}0.676 \\
(0.480)\end{array}$ & $\begin{array}{l}-0.026 \\
(0.167)\end{array}$ \\
\hline Non-democrat $\times$ Rents & $\begin{array}{c}0.001 \\
(0.002)\end{array}$ & $\begin{array}{c}-0.006^{* *} \\
(0.002)\end{array}$ & $\begin{array}{l}-0.064 \\
(0.039)\end{array}$ & $\begin{array}{l}-0.003 \\
(0.015)\end{array}$ \\
\hline Gov. exp. excl. edu. & & $\begin{array}{c}0.003 \\
(0.002)\end{array}$ & & $\begin{array}{l}-0.006 \\
(0.007)\end{array}$ \\
\hline Edu. exp. & & $\begin{array}{c}0.001 \\
(0.003)\end{array}$ & & $\begin{array}{c}-0.007 \\
(0.008)\end{array}$ \\
\hline Curr. acc. (\% GDP) & & $\begin{array}{c}-0.003^{*} \\
(0.002)\end{array}$ & & $\begin{array}{c}0.026^{* * *} \\
(0.008)\end{array}$ \\
\hline Constant & $\begin{array}{c}0.052 \\
(0.056)\end{array}$ & $\begin{array}{l}-0.009 \\
(0.071)\end{array}$ & $\begin{array}{c}-4.302^{* *} \\
(1.670)\end{array}$ & $\begin{array}{c}-1.248^{* * *} \\
(0.412)\end{array}$ \\
\hline Observations & 152 & 114 & 151 & 113 \\
\hline R-squared & 0.010 & 0.171 & 0.340 & 0.493 \\
\hline n. SWFs & 20 & 15 & 20 & 15 \\
\hline r2_a & -0.02 & 0.12 & 0.32 & 0.46 \\
\hline ll 139.83 & 128.87 & -214.12 & -69.31 & \\
\hline
\end{tabular}

Robust standard errors in parentheses

*** $\mathrm{p}<0.01,{ }^{* *} \mathrm{p}<0.05,{ }^{*} \mathrm{p}<0.1$ 
stock measures) the dependent variables. If country wide savings decision are taken based on the determinants we found before, then these same variables should have explanatory power in model with those variables on the left hand side. Since the net foreign assets and the foreign exchange reserves are continuous variables we can use simple OLS to estimate these models. As in the previous tables, we indicate for the sample the number of countries that have an SWF.

The results indicate that the variables we identified as explanatory variables for the SWFs, have in general much less if any explanatory power on the status of a country's financial position. The exception is GDP per capita and the current account, which contribute significantly and positively to the net foreign asset position. Their appears some correlation between the the polity variable in combination with rents for the foreign exchange reserves, where non-democracies hold on average $6.2 \%$ higher reserves decreasing with rents (model 2). However overall, if a country's economic policy, including national savings is a political decision we might have expected that education expenditures, rents as well as the government characters were strongly related to these measures. We find no strong evidence for this in contrast to the models on SWF establishment. Therefore, these results indicate that the emergence of SWFs is the result of a very different process than only balancing savings with respect to the rest of the world.

\subsection{Duration analysis}

Our data also allows us to do duration analysis, where we model the distribution of the time it takes to set up an SWF. Technically, we interpret our data as a stock sample with right censoring, since we take all countries that have no SWF in 1997, as the start of the spell, while not all countries will set up an SWF at the time our time period of analysis ends. For this reason duration models are interesting in our case since the feature of censoring allows us to take into account those countries without an SWF. We will present here just standard (parametric) duration models that fall in the proportional hazard class. The proportional hazard models imply that our covariates of interest are limited in shifting the hazard function (interpretable as the probability of failure at date $t$, given survival up to $t-1$ ) up or down over the entire time scale (i.e. the proportional effect of covariates do not change over time).

We report in Table 11 different specifications. We report coefficients. The effect of on the hazard function can be found by taking $\exp (\beta)-1$. Positive coefficient shift the hazard function upwards, indicating an increased probability of setting up an SWF relative to the baseline. The Cox and Weibull models are reported in columns (1) and (2) and lead to conclusions similar to those obtained in the benchmark table with a positive impact of funding (GDP per capita and resource rents are significant) and of autocracy, an interaction term between autocracy and resource rents that indicate that resources no longer matter in an autocratic country and a negative impact of government expenses (same results for education expenses - not reported in the Table). For the sake 
Table 11: Duration analysis

\begin{tabular}{|c|c|c|c|c|c|c|}
\hline & $(1)$ & $(2)$ & $(3)$ & $(4)$ & $(5)$ & $(6)$ \\
\hline VARIABLES & $\operatorname{cox}$ & full & full & democrat & autocrat & short sample \\
\hline \multirow[t]{2}{*}{$\overline{\text { Rents (\%GDP) }}$} & $0.150^{* * *}$ & $0.162^{* * *}$ & $0.177^{* * *}$ & $0.080^{* * *}$ & $0.030^{* *}$ & $0.155^{* * *}$ \\
\hline & $(0.031)$ & $(0.032)$ & $(0.039)$ & $(0.025)$ & $(0.015)$ & $(0.032)$ \\
\hline \multirow[t]{2}{*}{ Log GDPpc } & $1.253^{* * *}$ & $1.331^{* * *}$ & $1.533^{* * *}$ & $1.440 * * *$ & $1.041^{* * *}$ & $1.270 * * *$ \\
\hline & $(0.249)$ & $(0.250)$ & $(0.394)$ & $(0.403)$ & $(0.319)$ & $(0.245)$ \\
\hline \multirow[t]{2}{*}{ Non-democrat } & $1.981^{* * *}$ & $2.148^{* * *}$ & $2.439 * *$ & & & $2.040 * * *$ \\
\hline & $(0.695)$ & $(0.696)$ & $(0.996)$ & & & $(0.692)$ \\
\hline \multirow[t]{2}{*}{ Non-democrat $\times$ Rents } & $-0.123^{* * *}$ & $-0.135^{* * *}$ & $-0.151^{* * *}$ & & & $-0.128 * * *$ \\
\hline & $(0.035)$ & $(0.035)$ & $(0.044)$ & & & $(0.035)$ \\
\hline \multirow[t]{2}{*}{ Edu. exp. } & & & -0.200 & & & \\
\hline & & & $(0.205)$ & & & \\
\hline \multirow[t]{2}{*}{ Gov. exp. ex. edu. } & & & -0.019 & & & \\
\hline & & & $(0.057)$ & & & \\
\hline \multirow[t]{2}{*}{ Gov. cons. } & $-0.080^{*}$ & $-0.080^{*}$ & & $-0.151^{* *}$ & -0.038 & $-0.082^{*}$ \\
\hline & $(0.048)$ & $(0.047)$ & & $(0.073)$ & $(0.055)$ & $(0.048)$ \\
\hline \multirow[t]{2}{*}{ Constant } & & $-16.834^{* * *}$ & $-18.851^{* * *}$ & $-16.392^{* * *}$ & $-12.415^{* * *}$ & $-16.453^{* * *}$ \\
\hline & & $(2.571)$ & (4.109) & (3.996) & $(2.857)$ & $(2.470)$ \\
\hline Observations & 153 & 153 & 119 & 106 & $\overline{47}$ & 153 \\
\hline N. SWF & 21 & 21 & 16 & 11 & 10 & 21 \\
\hline 11 & -85.847 & -66.837 & -51.753 & -38.838 & -30.456 & -62.134 \\
\hline$\alpha$ & & 1.031 & 0.966 & 0.961 & 0.909 & 1.254 \\
\hline
\end{tabular}

of comparability with previous tables, the last column restricts the data on SWFs to the 1998-2008 periods, which keeps results unchanged, but increases slightly the estimates for the unconditional trend, suggesting that more and more SWFs are likely to be observed as time passes. However, comparing $\hat{\alpha}$ among the different models, indicates that the rate of SWF establishments is neither increasing nor decreasing with time (none of the estimated parameters is significantly different from 1).

\section{Predictions and characteristics}

The limited number of existing or newly established funds precludes making good statistical inference on them. Nevertheless it is revealing to look graphically to some of their characteristics in relation to the results we found above.

Firstly, we calculated the predicted probability for the establishment/existence of an SWF from Table 4 model (3). Subsequently, we plot this probability against the total size, fraction in foreign assets, accountability/transparency and behaviour. All the data come from Truman (2008), where the latter are ratings determined on publicly available information on their investment and reporting quality. We include in the plots all funds, including those established before 1998 as well as pension funds, allowing the observation of difference between such funds with respect to recent resource funded SWFs.

We see in the upper left plot that size is not related to the probability of the SWFs (ignoring the Singapore, which actually has no natural resource rents, there is no real 
Figure 2: Predicted probabilities vs. SWF characteristics
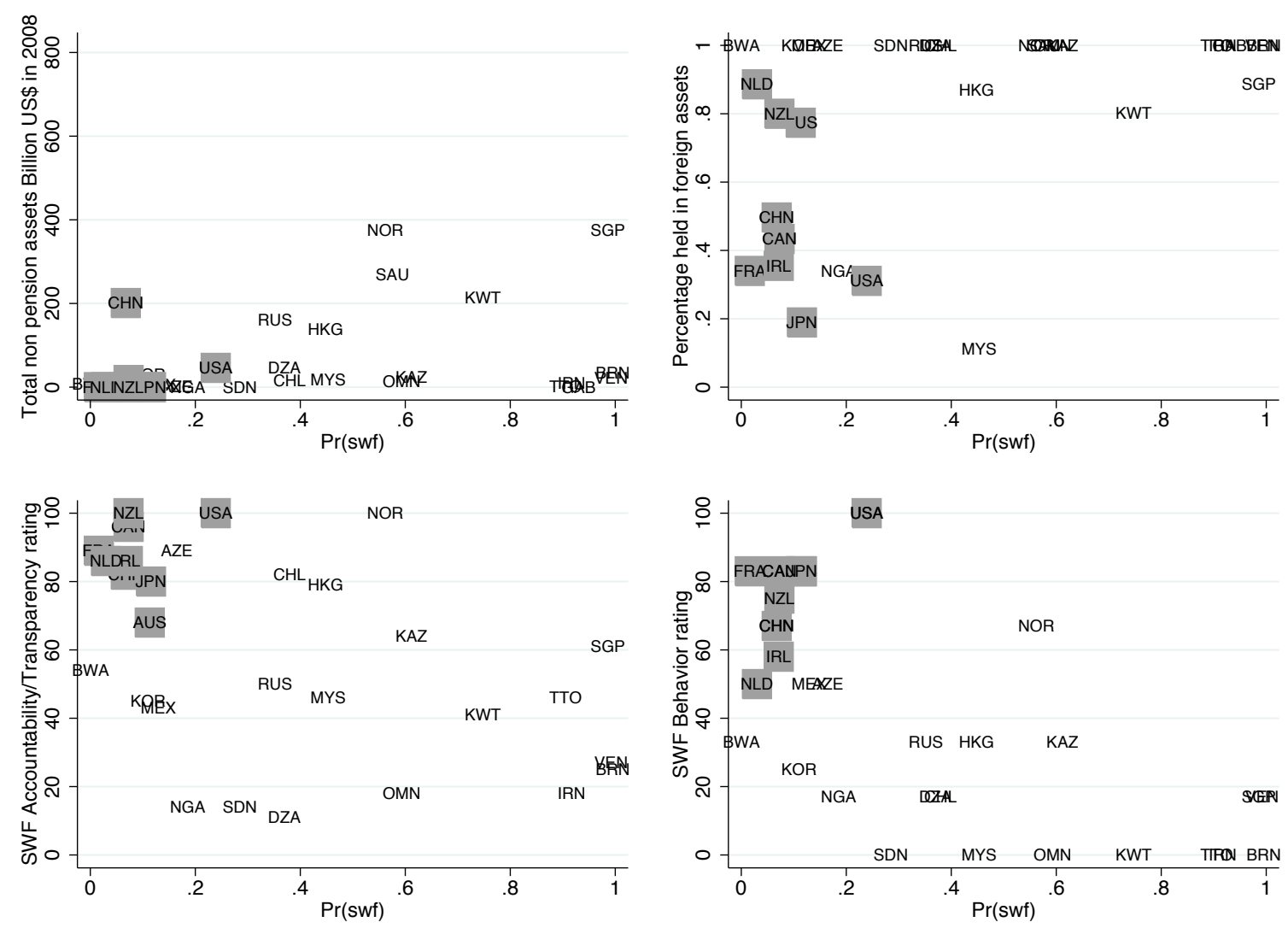

Note: Probabilities based on the model presented in Table 4 (4). Rectangles indicate pension funds, $\mathrm{X}$-axis predicted probability comes from Table 4 model (3). Y-axis variables come from Truman (2008).

pattern). ${ }^{23}$ This is interesting since the size of resource rents by itself was found to be positively related. In general, countries with some of the largest rents have a fund that is actually rather small. The largest funds, outside the Gulf countries, are dominated by western countries and China. The portion of assets invested abroad is $100 \%$ for quite some of the funds. Interestingly, western funds and China hold a significant fraction of their assets in domestic assets, except Norway. For the United States and Japan this makes sense as a global investment fund naturally includes a sizeable fraction of their own economy, while for smaller countries a global fund would have most assets abroad. However, this over-reliance could also indicate the lack of possibilities to invest domestically, which might be a valid explanation for Russia, Kazakhstan, Trinidad and Tobago, Iran and Venezuela. These countries might not be normally associated with capital scarcity, but known to be related to significant difficulties in establishing private and public sector investment opportunities.

\footnotetext{
${ }^{23}$ Reproducing this plot in terms of assets/GDP does not improve the presentation nor changes the pattern.
} 
Figure 3: predicted probabilities for all countries

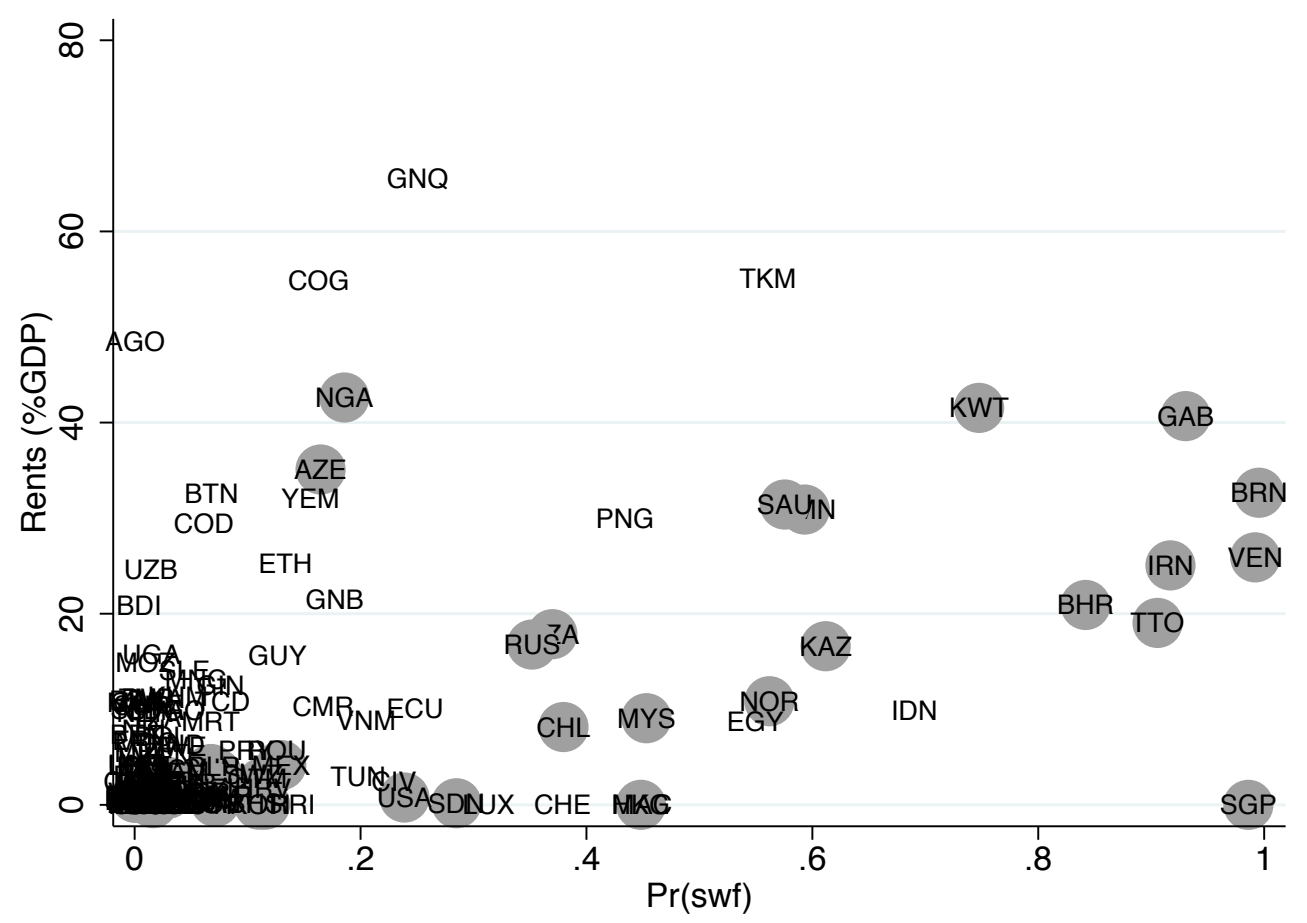

Circles indicate existing funds, both established before and after 1998. Here we compare "false positives' with "correct negatives" and "correct positives".

With respect to the quality of these funds construct and behaviour there is interesting pattern as well. Those countries with a high predicted probability of an SWF tend to have decreasing scores on the measures of accountability/transparency and behaviour. Pension funds score generally higher on these ratings than SWFs. It serves as a stark contract that those countries that have the highest prediction have the lowest scores on their quality standards, relative to those countries that have the lowest prediction but actually do have fund.

Finally, it is interesting to include all the data, meaning all the countries even if no fund exist. Figure 3 can reveal the false positives, as well as correct negatives. On the "false positives" side, say above 50\%, we have Turkmenistan (TKM), Indonesia (IDN) and Egypt (EGY). Just below that cut-off there is Papua New Guinea (PNG).

On the side of correct negatives we have Angola, Republic of Congo and Equitorial Guinea with sizeable resource rents but no SWF, while the predicted probability is also low. ${ }^{24}$ The score for Angola is low because the resource rent impact is cancelled out by its non-democratic structure. It scores below average on the education, spending around $2.5 \%$ of GDP. A similar explanation holds for Congo, which on top of that has a lower income per capita measure.

${ }^{24}$ Angola actually has set up an SWF in 2012, so fell out of our estimation sample of 1998-2008. 
In this graph it is also interesting to see the low probability of Azerbaijan (AZE). Its sizeable resource rents are predicted to be used domestically rather than for a fund. Compare this with the plots of Figure 2. The Azerbaijani SWF is small, completely into foreign assets and rather well organised. It appears to be ready to become a quality SWF once domestic opportunities for capital deepening are no longer necessary.

\section{Conclusion}

We presented evidence on the determinants for the establishment of Sovereign Wealth Funds. Based on recent literature of optimal policies for savings and investments of resource rich countries, we hypothesised the role of the key variables. We find, in line with the theory that, both economic and political aspects play an important role and interact. The observation that SWFs are related to non-democratic countries has triggered fears on their intention and goals. However, the reason for the establishment of SWFs appears strongly related to the domestic characteristics, including the economic opportunities, which in turn are related to how a country is organised politically. Democratic countries will have the mechanisms to direct windfalls to productive domestic uses which reduces the need for a fund full of foreign assets. Autocratic countries tend to create barriers for domestic private enterprises and often have purposely less well arranged public goods. SWFs then serve as an option for the elite to appear pragmatic but might just as well be related to the inability or unwillingness to make real changes at home. In contrast, in our estimations we find no strong evidence of the role of economic volatility or government indebtedness on the decision to setup an SWF.

The evidence presented here is in line with theoretical models that suggest that resource windfalls can be used in capital scarce countries to jump-start economic development. However, as in the debate on foreign aid, significant barriers for investment in public goods and the private sector may prohibit such beneficial uses. Instead SWF are nothing else than a failure of governments to share with their citizens the natural richness a country possesses.

For receivers of SWFs investments it may be relevant to appreciate these features. The results in this paper indicate that SWFs are phenomena of their origin, both economically and politically. As long as SWF home countries do not enact policies to stimulate growth, such funds will be around for a while.

We base these conclusions on a carefully executed econometric analysis given the data that we aimed to be include as many countries as possible. Admittedly, some of the variables that we looked at, including the dependent variable, may only be proxies of the variables that we are really interested in. Additionally, although we are able to identify factors that affect whether countries establish a SWF, and in extension how they manage their natural resources, the precise mechanism that work through these factors are not identified. Our results indicate that future research may very well successfully look further 
into the determinants and mechanisms of countries' resource management policies. 


\section{References}

Abbas, S. A., Belhocine, N., ElGanainy, A., and Horton, M. (2010) "A historical public debt database." IMF Working Paper WP/10/245.

Aizenman, J. and Glick, R. (2009) "Sovereign wealth funds: Stylized facts about their determinants and governance." International Finance, Vol. 12(3): 351-386.

Aizenman, J. and Glick, R. (2010). Asset class diversification and delegation of responsibilities between central banks and sovereign wealth funds. NBER Working Papers 16392, National Bureau of Economic Research, Inc.

Andersen, J. J., Johannesen, N., Lassen, D. D., and Paltseva, E. (2013) "Petro rents, political institutions, and hidden wealth: Evidence from bank deposits in tax havens." CAMP Working Paper Series No 7/2013.

Ang, A. (2012) "The four benchmarks of sovereign wealth funds." In Sovereign Wealth Funds and Long-Term Investing, edited by Bolton, P., Samama, F., and Stiglitz, J., pages 94-105. Columbia University Press.

Beck, R. and Fidora, M. (2008) "The impact of sovereign wealth funds on global financial markets." Intereconomics: Review of European Economic Policy, Vol. 43(6): 349-358.

Beine, M., Coulombe, S., and Vermeulen, W. N. (2014) "Dutch disease and the mitigation effect of migration: evidence from Canadian provinces." The Economic Journal. forthcoming.

Bernstein, S., Lerner, J., and Schoar, A. (2013) "The investment strategies of sovereign wealth funds." Journal of Economic Perspectives, Vol. 27(2): 219-38.

Collier, P. (2010) "The political economy of natural resources." Social Research, Vol. 77(4): 1105-1132.

Collier, P., van der Ploeg, F., Spence, M., and Venables, A. J. (2009). Managing resource revenues in developing economies. OxCarre Working Papers 015, Oxford Centre for the Analysis of Resource Rich Economies, University of Oxford.

Corden, W. M. (1984) "Booming sector and Dutch disease economics: survey and consolidation." Oxford Economic Papers, Vol. 36: 359-380.

Corden, W. M. and Neary, J. P. (1982) "Booming sector and de-industralisation in a small open economy." The Economic Journal, Vol. 92: 825-848.

Diwan, K. S. (2009) "Sovereign dilemmas: Saudi Arabia and sovereign wealth funds." Geopolitics, Vol. 14(2): 345-359. 
Gomes, T. (2008). The impact of sovereign wealth funds on international financial stability. Discussion Papers 08-14, Bank of Canada.

Hartwick, J. M. (1977) "Intergenerational equity and the ivesting of rents from exhaustible resources." American Economic Review, Vol. 67(5): 972-974.

In, F., Park, J. R., Ji, P. I., and Lee, B. (2013) "Do sovereign wealth funds stabilize stock markets?" Asia-Pacific Journal of Financial Studies Conference.

Johnson, S. (2007) "The rise of sovereign wealth funds." Finance and Development, Vol. 44(3): $56-57$.

Jordan, T. (2012) "Swiss national bank news conference, 14 june 2012." Press Release.

Kaufmann, D., Kraay, A., and Mastruzzi, M. (2009). Governance matters viii : aggregate and individual governance indicators 1996-2008. Policy Research Working Paper Series 4978, The World Bank.

Kirshner, J. (2009) "Sovereign wealth funds and national security: the dog that will refuse to bark." Geopolitics, Vol. 14(2): 305-316.

Kotter, J. and Lel, U. (2008). Friends or foes? the stock price impact of sovereign wealth fund investments and the price of keeping secrets. International Finance Discussion Papers 940, Board of Governors of the Federal Reserve System (U.S.).

Marshall, M. G., Gurr, T. R., and Jaggers, K. (2006) "Polity IV project. political regime characteristics and transitions, 1800-2013. dataset users' manual." Center for Systemic Peace.

Mehlum, H., Moene, K., and Torvik, R. (2006) "Institutions and the resource curse*." The Economic Journal, Vol. 116(508): 1-20.

Monk, A. (2009) "Recasting the sovereign wealth fund debate: trust, legitimacy, and governance." New Political Economy, Vol. 14(4): 451-468.

Raveh, O. (2013) "Dutch disease, factor mobility, and the alberta effect: the case of federations." Canadian Journal of Economics/Revue canadienne d'économique, Vol. 46(4): 1317-1350.

Robinson, J. A., Torvik, R., and Verdier, T. (2006) "The political foundations of the resource curse." Journal of Development Economics, Vol. 79: 447-468.

Robinson, J. A., Torvik, R., and Verdier, T. (2014) "Political foundations of the resource curse: A simplification and a comment." Journal of Development Economics, Vol. 106: 194-198. 
Rodrik, D. (2006) "The social cost of foreign exchange reserves." International Economic Journal, Vol. 20(3): 253-266.

Sachs, J. D. and Warner, A. M. (2001) "The curse of natural resources." European Economic Review, Vol. 45(4-6): 827-838.

Sun, T. and Hesse, H. (2009). Sovereign wealth funds and financial stability: an event study analysis. IMF Working Papers 09/239, International Monetary Fund.

Truman, E. M. (2008). A blueprint for sovereign wealth fund best practices. Policy Briefs PB08-3, Peterson Institute for International Economics.

van den Bremer, T. S. and van der Ploeg, F. (2013) "Managing and harnessing volatile oil windfalls." IMF Economic Review, Vol. 61(1): 130-167.

van der Ploeg, F. (2010a) "Aggressive oil extraction and precautionary saving: Coping with volatility." Journal of Public Economics, Vol. 94: 421-433.

van der Ploeg, F. (2010b) "Why do many resource-rich countries have negative genuine saving? anticipation of better times or rapacious rent seeking." Resource and Energy Economics, Vol. 32: 28-44.

van der Ploeg, F. (2011) "Natural resources: Curse or blessing?" Journal of Economic Literature, Vol. 49(2): 366-420.

van der Ploeg, F. (2012) "Bottlenecks in ramping up public investment." International Tax and Public Finance, Vol. 19(4): 509-538.

van der Ploeg, F. and Venables, A. J. (2011) "Harnessing windfall revenues: Optimal policies for resource-rich developing economies." Economic Journal, Vol. 121(551): 130 .

van der Ploeg, F. and Venables, A. J. (2013) "Absorbing a windfall of foreign exchange: Dutch disease dynamics." Journal of Development Economics, Vol. 103: 229-243.

Venables, A. (2010) "Resource rents; when to spend and how to save." International Tax and Public Finance, Vol. 17(4): 340-356.

Yi-Chong, X. and Bahgat, G. (2010). The Political Economy of Sovereign Wealth Funds. International Political Economy Series. 


\section{AppendixA. SWFs Overview and Data sources}

Table A-1: Assets (in billion USD) and inception of the 50 largest SWFs, as of end 2013

\begin{tabular}{|c|c|c|c|c|c|}
\hline Ranking & Country & SWF & Assets & Year & Inception $>1997 ?$ \\
\hline 1 & Norway & Government Pension Fund - Global & 818 & 1990 & 0 \\
\hline 2 & Saudi Arabia & SAMA Foreign Holdings & 675.9 & $\mathrm{n} / \mathrm{a}$ & 1 \\
\hline 3 & UAE - Abu Dhabi & Abu Dhabi Investment Authority & 627 & 1976 & 0 \\
\hline 4 & China & China Investment Corporation & 575.2 & 2007 & 1 \\
\hline 5 & China & SAFE Investment company & 567.9 & 1997 & 0 \\
\hline 6 & Kuwait & Kuwait Investment authority & 386 & 1953 & 0 \\
\hline 7 & Hong-Kong & HK Monetary Authority & 326.7 & 1993 & 0 \\
\hline 8 & Singapore & Government of Singapore Investment corporation & 285 & 1981 & 0 \\
\hline 9 & Singapore & Temasek Holdings & 173.3 & 1974 & 0 \\
\hline 10 & Qatar & Qatar Investment Authority & 170 & 2005 & 1 \\
\hline 11 & China & National Social Security Fund & 160.6 & 2000 & 1 \\
\hline 12 & Australia & Australian Future Fund & 88.7 & 2006 & 1 \\
\hline 13 & Russia & National Welfare Fund & 88 & 2008 & 1 \\
\hline 14 & Russia & Reserve Fund & 86.4 & 2008 & 1 \\
\hline 15 & Kazakhstan & Samruk-Kazyna JSC & 77.5 & 2008 & 1 \\
\hline 16 & Algeria & Revenue Regulation Fund & 77.2 & 2000 & 1 \\
\hline 17 & UAE- Duba & Investment Corporation of Duba & 70 & 2006 & 1 \\
\hline 18 & Kazakhstan & Kazakhstan National Fund & 68.9 & 2000 & 1 \\
\hline 19 & UAE - Abu Dhabi & International Petroleum Investment Company & 65.3 & 1984 & 0 \\
\hline 20 & Libya & Libyan Investment Authority & 65 & 2006 & 1 \\
\hline 21 & South Korea & Korean Investment Corporation & 56.6 & 2005 & 1 \\
\hline 22 & UAE - Abu Dhabi & Mubadala Development Company & 55.5 & 2002 & 1 \\
\hline 23 & Iran & National Development Fund of Iran & 54 & 2011 & 1 \\
\hline 24 & US - Alaska & Alaska Permanent Fund & 46.8 & 1976 & 0 \\
\hline 25 & Brunei & Brunei Investment Agency & 40 & 1983 & 0 \\
\hline 26 & Malaysia & Khasanah Nasional & 39.1 & 1993 & 0 \\
\hline 27 & Azerbaijan & State Oil Fund & 34.1 & 1999 & 1 \\
\hline 28 & France & Strategic Investment Fund & 25.5 & 2008 & 1 \\
\hline 29 & US - Texas & Texas Permanent School Fund & 25.5 & 1854 & 0 \\
\hline 30 & Kazakhstan & National Investment Corporation & 20 & 2012 & 1 \\
\hline 31 & Ireland & National Pensions Reserve Fund & 19.4 & 2001 & 1 \\
\hline 32 & New Zealand & NZ Superannuation Fund & 19.3 & 2003 & 1 \\
\hline 33 & Iraq & Development Fund for Iraq & 18 & 2003 & 1 \\
\hline 34 & US - New Mexico & New Mexico State Investment Council & 17.3 & 1958 & 0 \\
\hline 35 & Canada & Alberta's Heritage Fund & 16.4 & 1976 & 0 \\
\hline 36 & US - Texas & Permanent University Fund & 15.3 & 1876 & 0 \\
\hline 37 & Chile & Social and Economic Stabilization Fund & 15.2 & 2007 & 1 \\
\hline 38 & East Timor & Timor-Leste Petroleum Fund & 14.6 & 2005 & 1 \\
\hline 39 & Russia & Russian Direct Investment Fund & 13 & 2011 & 1 \\
\hline 40 & UAE - Federal & Emirates Investment Authority & 10 & 2007 & 1 \\
\hline 41 & Oman & State General Reserve Fund & 8.2 & 1980 & 0 \\
\hline 42 & Bahrain & Mumtalakat Holding Company & 7.1 & 2006 & 1 \\
\hline 43 & Peru & Fiscal stabilization Fund & 7.1 & 1999 & 1 \\
\hline 44 & Chile & Pension Reserve Fund & 7 & 2006 & 1 \\
\hline 45 & Botswana & Pula Fund & 6.9 & 1994 & 0 \\
\hline 46 & Mexico & Oil Revenues Stabilization Fund of Mexico & 6 & 2000 & 1 \\
\hline 47 & Oman & Oman Investment Fund & 6 & 2006 & 1 \\
\hline 48 & Italy & Italian Strategic Fund & 6 & 2011 & 1 \\
\hline 49 & US - Wyoming & Permanent Wyoming Mineral Trust Fund & 5.6 & 1974 & 0 \\
\hline 50 & Brazil & Sovereign fund of Brazil & 5.3 & 2008 & 1 \\
\hline TOTAL & 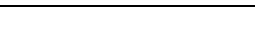 & & 6073.40 & 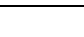 & 32 \\
\hline
\end{tabular}


Table A-2: Data Description

\begin{tabular}{|c|c|c|}
\hline Variable & Description & Source \\
\hline$\overline{\mathrm{SWF}}$ & Country dummy equal to 1 if the country established & Truman $\quad$ (2008) \\
\hline & his first SWF in the $1998-2008$ period, to 0 otherwise & www.swfinstitute.org \\
\hline Rents & Total Natural Resources Rents (\% of GDP) & WB WDI (ny.gdp.totl.rt.zs) \\
\hline Log GDPpc & log GDP per Capita, constant US $\$$, millions & WB indicators (GDPPCKD) \\
\hline Non-democrat. & $\begin{array}{l}\text { Country dummy equal to } 1 \text { if polity } 2 \text { is smaller or equal } \\
\text { to } 0 \text {, to } 0 \text { otherwise }\end{array}$ & Polity IV Project \\
\hline Edu. exp. & Public spending on education, total (\% of GDP) & WB WDI (se.xpd.totl.gd.zs) \\
\hline Gov. cons. & $\begin{array}{l}\text { General government final consumption expenditure (\% } \\
\text { of GDP) }\end{array}$ & WB WDI (ne.con.govt.zs) \\
\hline Curr. acc. & Current Account Balance, \%GDP & WB indicators (bncabfundcd) \\
\hline Debt & Sovereign debt ( $\%$ of GDP) & Abbas et al. (2010) \\
\hline NFA & Net Financial Assets, excluding gold (\% of GDP) & $\begin{array}{l}\text { Lane and Milesi-Ferretti (2007) as up- } \\
\text { dated/extended }\end{array}$ \\
\hline FXRes & Foreign Exchange reserves, excluding gold ( $\%$ of GDP) & $\begin{array}{l}\text { Lane and Milesi-Ferretti (2007) as up- } \\
\text { dated/extended }\end{array}$ \\
\hline$\sigma^{2}(G D P)$ & Coefficient of variation of GDP over 1978-1998 & WB WDI (ny.gdp.mktp.cd) \\
\hline$\sigma^{2}($ Rents $)$ & Coefficient of variation of Rents over 1978-1998 & WB WDI (ny.gdp.totl.rt.zs) \\
\hline Gini & GINI index & WB WDI (si.pov.gini) \\
\hline Log GDPpc/(100-Gini) & logarithm of GDP per capita as divided by (100-Gini) & $\begin{array}{l}\text { WB WDI (si.pov.gini and GDP- } \\
\text { PCKD) }\end{array}$ \\
\hline Natural gas rents & Natural gas rents ( $\%$ of GDP) & WB WDI (ny.gdp.ngas.rt.zs) \\
\hline Oil rents & Oil rents ( $\%$ of GDP) & WB WDI (ny.gdp.petr.rt.zs) \\
\hline Commodity Exp. & $\begin{array}{l}\text { Primary commodities (\% total exports) over 1995- } \\
1998\end{array}$ & $\begin{array}{l}\text { UNCTADstat (SITC } 0+1+2+3+ \\
4+68)\end{array}$ \\
\hline xrreg & regulation of chief executive recruitment & Polity IV Project \\
\hline xrcomp & competitiveness of executive recruitment & Polity IV Project \\
\hline xropen & openness of executive recruitmente & Polity IV Project \\
\hline xconst & executive constraints (decision rules) & Polity IV Project \\
\hline parreg & regulation of participation & Polity IV Project \\
\hline parcomp & the competitiveness of participation & Polity IV Project \\
\hline exrec & executive recruitment concept & Polity IV Project \\
\hline exconst & executive constraints concept & Polity IV Project \\
\hline polcomp & political competition concept & Polity IV Project \\
\hline
\end{tabular}




\section{AppendixB. Additional results}

Table B-1: Forms of log GDPpc and Education

\begin{tabular}{|c|c|c|c|c|}
\hline & $\begin{array}{l}1) \\
\text { swf }\end{array}$ & $\begin{array}{l}(2) \\
\text { swf } \\
\end{array}$ & $\begin{array}{c}(3) \\
\text { swf }\end{array}$ & $\begin{array}{l}(4) \\
\text { swf }\end{array}$ \\
\hline Rents (\%GDP) & $\begin{array}{c}0.245^{* * *} \\
(0.061)\end{array}$ & $\begin{array}{c}0.239^{* * *} \\
(0.063)\end{array}$ & $\begin{array}{c}0.305^{* * *} \\
(0.078)\end{array}$ & $\begin{array}{c}0.279 * * * \\
(0.088)\end{array}$ \\
\hline Log GDPpc & $\begin{array}{c}1.756^{* * *} \\
(0.438)\end{array}$ & $\begin{array}{c}12.837^{*} \\
(6.574)\end{array}$ & $\begin{array}{c}2.297^{* * *} \\
(0.614)\end{array}$ & $\begin{array}{c}1.961^{* * *} \\
(0.511)\end{array}$ \\
\hline$(\log \text { GDPpc })^{2}$ & & $\begin{array}{c}-0.617^{*} \\
(0.351)\end{array}$ & & \\
\hline Non-democrat & $\begin{array}{c}3.279^{*} \\
(1.782)\end{array}$ & $\begin{array}{c}3.085 \\
(1.947)\end{array}$ & $\begin{array}{c}5.385^{* *} \\
(2.115)\end{array}$ & $\begin{array}{c}3.101 \\
(2.108)\end{array}$ \\
\hline Non-democrat $\times$ Rents & $\begin{array}{c}-0.222^{* * *} \\
(0.082)\end{array}$ & $\begin{array}{c}-0.218^{* *} \\
(0.085)\end{array}$ & $\begin{array}{c}-0.279^{* *} \\
(0.112)\end{array}$ & $\begin{array}{l}-0.195 \\
(0.121)\end{array}$ \\
\hline $\begin{array}{l}\text { Edu. exp. } \\
(\text { Edu. exp. })^{2}\end{array}$ & $\begin{array}{l}-0.509 \\
(0.422)\end{array}$ & $\begin{array}{l}-0.498 \\
(0.501)\end{array}$ & $\begin{array}{c}8.313^{* *} \\
(3.299) \\
-1.408^{* * *} \\
(0.483)\end{array}$ & $\begin{array}{l}-0.489 \\
(0.395)\end{array}$ \\
\hline $\begin{array}{l}\text { Gov. exp. excl. edu. } \\
(\text { Gov. exp. excl. edu. })^{2}\end{array}$ & $\begin{array}{l}-0.198 \\
(0.123)\end{array}$ & $\begin{array}{l}-0.192 \\
(0.134)\end{array}$ & $\begin{array}{l}-0.303 \\
(0.232)\end{array}$ & $\begin{array}{c}3.165^{* *} \\
(1.379) \\
-0.178^{* *} \\
(0.081)\end{array}$ \\
\hline Constant & $\begin{array}{c}-16.037^{* * *} \\
(3.828)\end{array}$ & $\begin{array}{c}-65.275^{* *} \\
(30.288)\end{array}$ & $\begin{array}{c}-33.276^{* * *} \\
(7.529)\end{array}$ & $\begin{array}{c}-32.934^{* * *} \\
(9.631)\end{array}$ \\
\hline Observations & 115 & 115 & 115 & 115 \\
\hline n. SWFs & 11 & 11 & 11 & 11 \\
\hline Pseudo $\mathrm{R}^{2}$ & 0.42 & 0.46 & 0.56 & 0.53 \\
\hline 11 & -20.89 & -19.70 & -15.84 & -17.01 \\
\hline
\end{tabular}


Table B-2: Interaction with rents

\begin{tabular}{lcccc}
\hline & $(1)$ & $(2)$ & $(3)$ & $(4)$ \\
interaction variable & Rents & Log GDPpc & Non-democrat & Gov. cons \\
\hline Rents (\%GDP) & $0.311^{* * *}$ & $-1.518^{*}$ & $0.262^{* * *}$ & 0.033 \\
& $(0.104)$ & $(0.893)$ & $(0.058)$ & $(0.081)$ \\
Log GDPpc & $1.753^{* * *}$ & 0.399 & $1.954^{* * *}$ & $1.384^{* * *}$ \\
& $(0.383)$ & $(0.436)$ & $(0.390)$ & $(0.311)$ \\
Non-democrat & 0.868 & $1.367^{*}$ & $3.926^{* * *}$ & 1.341 \\
& $(1.003)$ & $(0.730)$ & $(1.172)$ & $(0.939)$ \\
interaction var. $\times$ Rents & $-0.005^{* * *}$ & $0.185^{*}$ & $-0.241^{* * *}$ & 0.002 \\
& $(0.002)$ & $(0.103)$ & $(0.066)$ & $(0.004)$ \\
Gov. cons. & $-0.213^{* * *}$ & $-0.196^{* * *}$ & $-0.249^{* * *}$ & $-0.237^{* * *}$ \\
& $(0.071)$ & $(0.066)$ & $(0.071)$ & $(0.081)$ \\
Constant & $-16.844^{* * *}$ & -3.921 & $-18.468^{* * *}$ & $-12.080^{* * *}$ \\
& $(3.799)$ & $(3.425)$ & $(3.545)$ & $(2.605)$ \\
Observations & & & & 149 \\
n. SWFs & 149 & 149 & 149 & 16 \\
Pseudo R & 16 & 16 & 16 & 0.29 \\
ll & 0.42 & 0.43 & 0.42 & -36.31 \\
\hline
\end{tabular}

Robust standard errors in parentheses

*** $\mathrm{p}<0.01,{ }^{* *} \mathrm{p}<0.05,{ }^{*} \mathrm{p}<0.1$ 
Table B-3: Alternative results Table 6

\begin{tabular}{|c|c|c|c|c|c|}
\hline & $\begin{array}{l}1) \\
\text { swf }\end{array}$ & $\begin{array}{l}(2) \\
\text { swf }\end{array}$ & $\begin{array}{l}3) \\
\text { swf }\end{array}$ & $\begin{array}{l}4) \\
\text { swf }\end{array}$ & $\begin{array}{l}(5) \\
\text { swf }\end{array}$ \\
\hline Rents (\%GDP) & $\begin{array}{c}0.235^{* * *} \\
(0.059)\end{array}$ & $\begin{array}{c}0.292^{* * *} \\
(0.093)\end{array}$ & $\begin{array}{c}0.243^{* * *} \\
(0.060)\end{array}$ & $\begin{array}{c}0.289^{* * *} \\
(0.065)\end{array}$ & $\begin{array}{c}0.242^{* * *} \\
(0.060)\end{array}$ \\
\hline Log GDPpc & $\begin{array}{c}1.754^{* * *} \\
(0.478)\end{array}$ & $\begin{array}{c}1.811 * * * \\
(0.555)\end{array}$ & $\begin{array}{c}1.884^{* * *} \\
(0.472)\end{array}$ & $\begin{array}{c}1.671^{* * *} \\
(0.481)\end{array}$ & $\begin{array}{c}1.858^{* * *} \\
(0.499)\end{array}$ \\
\hline Non-democrat & $\begin{array}{l}2.980^{*} \\
(1.690)\end{array}$ & $\begin{array}{l}3.251^{*} \\
(1.837)\end{array}$ & $\begin{array}{l}3.256^{*} \\
(1.894)\end{array}$ & $\begin{array}{c}3.727^{* *} \\
(1.721)\end{array}$ & $\begin{array}{l}3.301^{*} \\
(1.799)\end{array}$ \\
\hline Non-democrat $\times$ Rents & $\begin{array}{c}-0.190^{* *} \\
(0.077)\end{array}$ & $\begin{array}{c}-0.219^{* *} \\
(0.097)\end{array}$ & $\begin{array}{c}-0.217^{* *} \\
(0.085)\end{array}$ & $\begin{array}{c}-0.274^{* * *} \\
(0.091)\end{array}$ & $\begin{array}{c}-0.221^{* * *} * \\
(0.082)\end{array}$ \\
\hline Gov. exp. excl. edu. & $\begin{array}{l}-0.197 \\
(0.143)\end{array}$ & $\begin{array}{l}-0.136 \\
(0.135)\end{array}$ & $\begin{array}{l}-0.222 \\
(0.144)\end{array}$ & $\begin{array}{c}-0.234^{* *} \\
(0.119)\end{array}$ & $\begin{array}{l}-0.173 \\
(0.117)\end{array}$ \\
\hline Edu. exp. & $\begin{array}{l}-0.539 \\
(0.423)\end{array}$ & $\begin{array}{l}-0.749^{*} \\
(0.454)\end{array}$ & $\begin{array}{l}-0.514 \\
(0.438)\end{array}$ & $\begin{array}{l}-0.372 \\
(0.380)\end{array}$ & $\begin{array}{l}-0.548 \\
(0.427)\end{array}$ \\
\hline Curr. Acc. (\% GDP) & $\begin{array}{c}0.027 \\
(0.038)\end{array}$ & & & & \\
\hline NFA ( \% GDP) & & $\begin{array}{c}1.762 \\
(1.205)\end{array}$ & & & \\
\hline FXRes (\% GDP) & & & $\begin{array}{c}0.366 \\
(4.191)\end{array}$ & & \\
\hline$\sigma^{2}(\mathrm{GDP})$ & & & & $\begin{array}{c}3.608 \\
(3.049)\end{array}$ & \\
\hline$\sigma^{2}$ (Rents) & & & & & $\begin{array}{l}-0.367 \\
(0.413)\end{array}$ \\
\hline Constant & $\begin{array}{c}-15.695^{* * *} \\
(3.929)\end{array}$ & $\begin{array}{c}-15.889^{* * *} \\
(4.753)\end{array}$ & $\begin{array}{c}-16.895^{* * *} \\
(3.917)\end{array}$ & $\begin{array}{c}-17.209^{* * *} \\
(4.176)\end{array}$ & $\begin{array}{c}-16.800^{* * *} \\
(4.277)\end{array}$ \\
\hline Observations & 110 & 112 & 113 & 115 & 112 \\
\hline n. SWFs & 11 & 11 & 11 & 11 & 11 \\
\hline Pseudo $\mathrm{R}^{2}$ & 0.44 & 0.49 & 0.44 & 0.45 & 0.42 \\
\hline ll & -20.14 & -18.50 & -20.32 & -20.09 & -20.69 \\
\hline
\end{tabular}

Robust standard errors in parentheses ${ }^{* * *} \mathrm{p}<0.01,{ }^{* *} \mathrm{p}<0.05,{ }^{*} \mathrm{p}<0.1$ 
Table B-4: Additional results Table 6, Debt

\begin{tabular}{|c|c|c|c|c|}
\hline & $\begin{array}{l}(1) \\
\text { swf }\end{array}$ & $\begin{array}{c}(2) \\
\text { swf }\end{array}$ & $\begin{array}{c}(3) \\
\text { swf }\end{array}$ & $\begin{array}{c}(4) \\
\text { swf }\end{array}$ \\
\hline Rents (\%GDP) & $\begin{array}{c}0.217^{* * *} \\
(0.056)\end{array}$ & $\begin{array}{c}0.257^{* * *} \\
(0.060)\end{array}$ & $\begin{array}{c}0.335^{* * *} \\
(0.098)\end{array}$ & $\begin{array}{c}0.357^{* * *} \\
(0.107)\end{array}$ \\
\hline Log GDPpc & $\begin{array}{c}1.326^{* * *} \\
(0.337)\end{array}$ & $\begin{array}{c}1.891^{* * *} \\
(0.494)\end{array}$ & $\begin{array}{l}1.421^{* *} \\
(0.604)\end{array}$ & $\begin{array}{l}1.148^{* *} \\
(0.576)\end{array}$ \\
\hline Non-democrat & $\begin{array}{c}3.123^{* * *} \\
(1.049)\end{array}$ & $\begin{array}{c}3.915^{* * *} \\
(1.250)\end{array}$ & $\begin{array}{c}2.389 \\
(1.535)\end{array}$ & $\begin{array}{l}2.270^{*} \\
(1.323)\end{array}$ \\
\hline Non-democrat $\times$ Rents & $\begin{array}{c}-0.188^{* * *} \\
(0.065)\end{array}$ & $\begin{array}{c}-0.231^{* * *} \\
(0.073)\end{array}$ & $\begin{array}{c}-0.202^{* *} \\
(0.093)\end{array}$ & $\begin{array}{c}-0.234^{* *} \\
(0.105)\end{array}$ \\
\hline Gov. exp. excl. edu. & & & $\begin{array}{c}-0.248^{* *} \\
(0.112)\end{array}$ & \\
\hline Edu. exp. & & & $\begin{array}{c}-0.284 \\
(0.300)\end{array}$ & \\
\hline Debt & $\begin{array}{l}-0.010 \\
(0.014)\end{array}$ & $\begin{array}{l}-0.010 \\
(0.012)\end{array}$ & $\begin{array}{c}-0.072^{* * *} \\
(0.025)\end{array}$ & $\begin{array}{c}-0.064^{* * *} \\
(0.018)\end{array}$ \\
\hline Gov. cons. & & $\begin{array}{c}-0.270 * * * \\
(0.087)\end{array}$ & & \\
\hline Constant & $\begin{array}{c}-15.409 * * * \\
(3.663)\end{array}$ & $\begin{array}{c}-16.920^{* * *} \\
(4.536)\end{array}$ & $\begin{array}{c}-10.884^{* *} \\
(5.379)\end{array}$ & $\begin{array}{c}-12.250^{* *} \\
(5.738)\end{array}$ \\
\hline Observations & 148 & 143 & 112 & 112 \\
\hline n. SWFs & 16 & 16 & 11 & 11 \\
\hline Pseudo $\mathrm{R}^{2}$ & 0.33 & 0.44 & 0.61 & 0.53 \\
\hline 11 & -33.74 & -27.94 & -14.06 & -16.94 \\
\hline
\end{tabular}

Robust standard errors in parentheses

$* * * \mathrm{p}<0.01,{ }^{* *} \mathrm{p}<0.05,{ }^{*} \mathrm{p}<0.1$ 
Table B-5: Additional results Table 4: constant sample size

\begin{tabular}{|c|c|c|c|c|c|c|}
\hline VARIABLES & $\begin{array}{l}(1) \\
\text { swf }\end{array}$ & $\begin{array}{c}(2) \\
\text { swf }\end{array}$ & $\begin{array}{l}(3) \\
\text { swf }\end{array}$ & $\begin{array}{c}(4) \\
\text { swf }\end{array}$ & $\begin{array}{l}(5) \\
\text { swf }\end{array}$ & $\begin{array}{l}6) \\
\text { swf }\end{array}$ \\
\hline Rents (\%GDP) & $\begin{array}{c}0.245^{* * *} \\
(0.061)\end{array}$ & $\begin{array}{c}0.252^{* * *} \\
(0.066)\end{array}$ & $\begin{array}{c}0.240^{* * * *} \\
(0.058)\end{array}$ & $\begin{array}{c}0.267^{* * *} \\
(0.063)\end{array}$ & $\begin{array}{c}0.259^{* * *} \\
(0.065)\end{array}$ & $\begin{array}{l}0.063^{*} \\
(0.033)\end{array}$ \\
\hline Log GDPpc & $\begin{array}{c}1.756^{* * * *} \\
(0.438)\end{array}$ & $\begin{array}{c}1.458^{* * *} \\
(0.410)\end{array}$ & $\begin{array}{c}1.654^{* * * *} \\
(0.395)\end{array}$ & $\begin{array}{c}1.842^{* * *} \\
(0.471)\end{array}$ & $\begin{array}{c}1.390^{* * *} \\
(0.392)\end{array}$ & $\begin{array}{c}0.786^{* * *} \\
(0.230)\end{array}$ \\
\hline Non-democrat & $\begin{array}{l}3.279^{*} \\
(1.782)\end{array}$ & $\begin{array}{c}2.601^{* *} \\
(1.262)\end{array}$ & $\begin{array}{c}2.931^{* *} \\
(1.292)\end{array}$ & $\begin{array}{l}3.720^{* *} \\
(1.578)\end{array}$ & $\begin{array}{c}2.843^{* *} \\
(1.166)\end{array}$ & $\begin{array}{c}0.226 \\
(1.139)\end{array}$ \\
\hline Non-democrat $\times$ Rents & $\begin{array}{c}-0.222^{* * *} \\
(0.082)\end{array}$ & $\begin{array}{c}-0.219^{* * *} \\
(0.072)\end{array}$ & $\begin{array}{c}-0.204^{* * *} \\
(0.065)\end{array}$ & $\begin{array}{c}-0.267^{* * *} \\
(0.077)\end{array}$ & $\begin{array}{c}-0.235^{* * *} \\
(0.068)\end{array}$ & \\
\hline Edu. exp. & $\begin{array}{l}-0.509 \\
(0.422)\end{array}$ & & & $\begin{array}{c}-0.733^{* *} \\
(0.318)\end{array}$ & & \\
\hline Gov. exp. excl. edu. & $\begin{array}{l}-0.198 \\
(0.123)\end{array}$ & $\begin{array}{c}-0.073^{*} \\
(0.043)\end{array}$ & & & & \\
\hline Gov. cons. & & & $\begin{array}{c}-0.261^{* * *} \\
(0.075)\end{array}$ & & & \\
\hline Constant & $\begin{array}{c}-16.037 * * * \\
(3.828)\end{array}$ & $\begin{array}{c}-16.461^{* * *} \\
(4.284)\end{array}$ & $\begin{array}{c}-15.348^{* * *} \\
(3.539)\end{array}$ & $\begin{array}{c}-18.145^{* * *} \\
(4.255)\end{array}$ & $\begin{array}{c}-16.700^{* * *} \\
(4.185)\end{array}$ & $\begin{array}{c}-9.906^{* * *} \\
(2.257)\end{array}$ \\
\hline Observations & 115 & 115 & 115 & 115 & 115 & 115 \\
\hline n. SWFs & 11 & 11 & 11 & 11 & 11 & 11 \\
\hline Pseudo $\mathrm{R}^{2}$ & 0.42 & 0.34 & 0.42 & 0.38 & 0.31 & 0.16 \\
\hline 11 & -20.89 & -24.04 & -21.17 & -22.31 & -25.07 & -30.43 \\
\hline
\end{tabular}


Figure B-1: Robustness check - sensibility to country exclusion

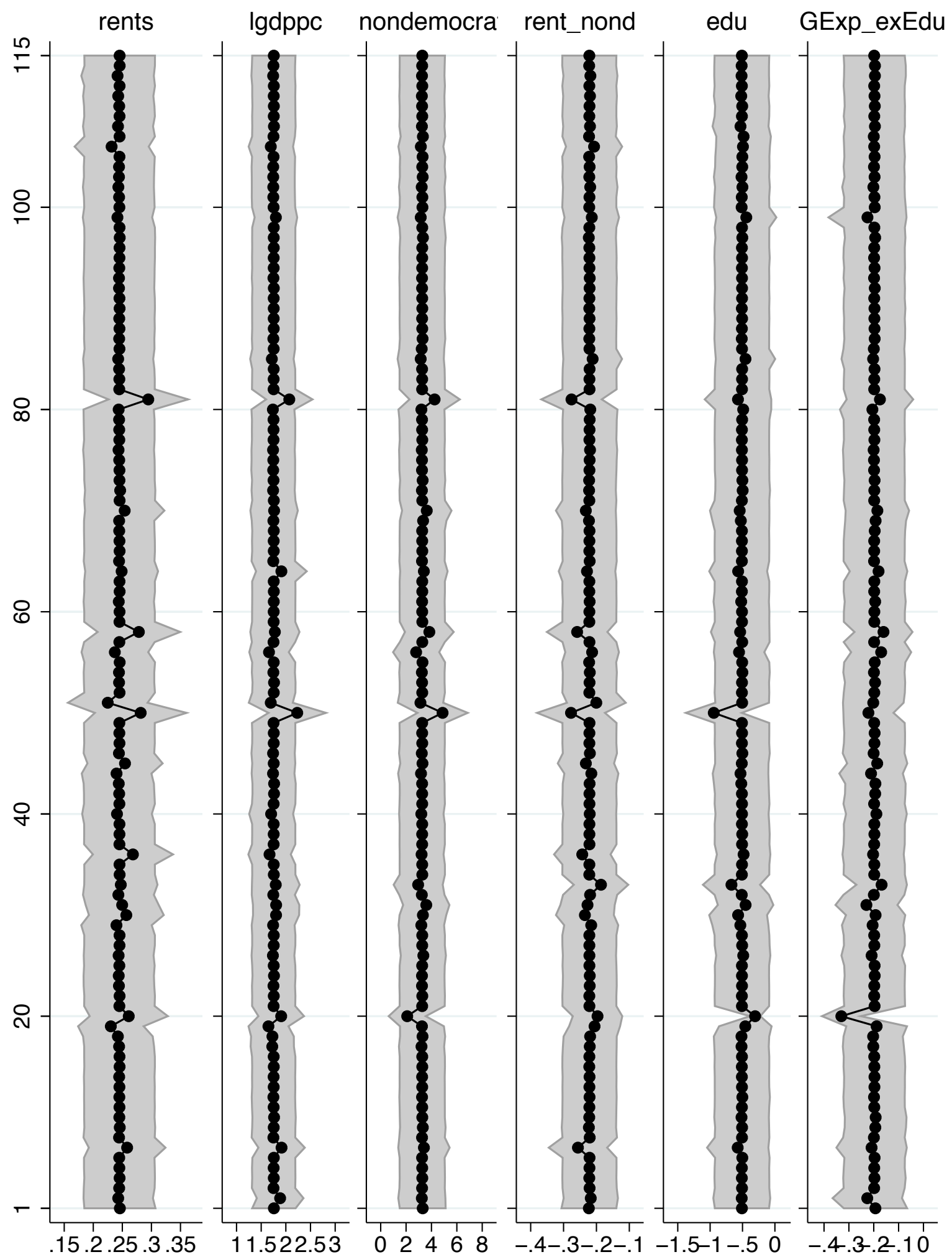

Note: graphs indicate coefficient on the regressors whilst excluding one observation per estimation, shaded area is $95 \%$ confidence interval. The variables refer to the five regressors in the benchmark model, non-democrat is the dummy, "rent_nond" is the interaction of nondemocracy with rents, "edu" is educational expenditures and "GExp_exEdu" is Government consumption excluding education. Results seem generally stable, the occasional peaks are predominantly away from zero. 